\title{
On the Modeling of Air Flow in the Tombs of the Valley of Kings
}

Essam E Khali1 ${ }^{1,2 *}$

${ }^{1}$ Chairman Arab HVAC Code Committee ASHRAE Director-At-Large, USA, Convenor ISO TC205 WG2, Co-Convenor ISO TC163 WG4, Deputy Director (International) AIAA, USA

${ }^{2}$ DIC, Professor of Mechanical Engineering, Cairo University, Cairo, Egypt

\begin{abstract}
The tombs of the kings in Valley of the Kings, Luxor, are considered to be one of the tourism industry's bases in Egypt due to their uniqueness all over the world. Hence, they should be preserved from the different factors that might cause harm for their wall paintings. One of these factors is the excessive relative humidity as it increases the bacteria and fungus activity inside the tomb in addition to its effect on the mechanical and physical properties of materials. This chapter describes the Research work to design ventilation systems to some of these important tombs. The chapter aims to investigate, design, and implement controlled climate to the tombs of the valley of kings with complete monitoring of air properties, temperature, relative humidity and carbon oxides and air quality parameters mechanical distributions inside selected tombs of the valley of the kings that are open for visitors. A complete climate control and monitoring of air will be effected with the aid of a mechanical ventilation system extracting air at designated locations in the wooden raised floor of the tombs. The location, size and extracted air are to be predicted and optimized the use of Computational Fluid Dynamics software (CFD). The CFD modelling techniques would solve the continuity, momentum, energy, and species transport equations in addition to k-epsilon model equations for turbulence closure. The SIMPLEC algorithm is used for the pressure-velocity coupling and a second order upwind scheme was use for discretization of the governing equations. Mesh sizes used in the present work exceeded 700,000 mesh volumes to adequately represent the flow characteristics at various locations.

Throughout the first phase of this investigation, the outside air conditions, number of visitors, and airside system design effect on the tombs' airflow characteristics will be studied in order to reach the optimum ventilation design as well as the favourable working conditions for a particular tomb. Mechanical engineering design of air flow system including under raised floor flexible duct routings, sizes, grills locations etc. with be provided in professional design drawing to be used as bases for execution and installation at the second phase. A complete set of measuring and monitoring equipment will be installed for each tomb to intelligently direct the visitors to the tomb where relative humidity and $\mathrm{CO}_{2}$ levels are permissible. A permissible number of the simultaneous of visitors for each tomb should be made in order to limit the relative humidity inside any given tomb.
\end{abstract}

\section{Basic Requirements Include}

1. Preserve the tombs and their archeological contents.

2. No excessive Humidity Ratio.

3. No high air Velocity near Paintings.

4. No Mechanical Vibrating Installations.

5. No permanent Installations.

6. Adequate up lighting.

\section{Introduction}

\section{General}

The tourism in Egypt is one of the national income supports which helps in increasing the standard of living. The Tombs of the kings, Luxor, Egypt is considered one of the most important Egyptian Pharaohs heritage and one the favourite places for visiting. The human comfort is a critical issue to study to help more tourists to visit with no complaint. Relative humidity (Moisture content), temperature, mechanical vibrations, lighting, noise and insects are the main factors given attention as their significant influence on both human and artifacts. The monuments of the Valley of the Kings are under serious threat, both from natural phenomena (flash-flooding) and from the constant demands of tourism. The wall paintings in the Valley represent the greatest collection of ancient art in the world. As Egypt's Ministry of Culture and Supreme Council of Antiquities are only too aware, dramatic steps must and are being taken to control the situation, reverse current trends and ensure the tombs' continuing survival. There are many factors which affects badly in the artifacts divided to external factors and internal factors (Annexure 1) [1-5]

External factors: The biggest threat is flood water penetration by flash flooding, as illustrated by the dramatic and tragic events during 1994. Incidents of heavy rains in the Theban Mountains are not unusual and have been noted from ancient times. Several tombs in the Valley of the Kings are completely choked or contain chambers that are thoroughly encumbered with the debris of flooding. In constructing schemes to prevent flood water damage to tombs in the Valley of the Kings one can learn lessons from the history of archaeology. It is worthwhile to examine the context of those discoveries in which the contents of tombs were found dry and well preserved. Rainwater, windstorm and others natural emergencies has a weak affect in the archaeological artifacts but its impact is less than flood water.

Internal factors: We take these factors into consideration in this work to reach to the optimum method for protection of the artifacts.

*Corresponding author: Khalil EE, Ph.D London, Chairman Arab HVAC Code Committee ASHRAE Director-At-Large, USA, Convenor ISO TC205 WG2, CoConvenor ISO TC163 WG4, Deputy Director (International) AIAA, USA, Tel: +20122-2116611/+1-202-3860163; Fax.+20-2-33362433; E-mail: khalile1@asme.org

Received May 20, 2017; Accepted July 02, 2017; Published July 10, 2017

Citation: Khalil EE (2017) On the Modeling of Air Flow in the Tombs of the Valley of Kings. Fluid Mech Open Acc 4: 166. doi: 10.4172/2476-2296.1000166

Copyright: $\odot 2017$ Khalil EE. This is an open-access article distributed under the terms of the Creative Commons Attribution License, which permits unrestricted use, distribution, and reproduction in any medium, provided the original author and source are credited. 
Citation: Khalil EE (2017) On the Modeling of Air Flow in the Tombs of the Valley of Kings. Fluid Mech Open Acc 4: 166. doi: 10.4172/24762296.1000166

Following are detailed representation of these threats and management guidelines [6].

Relative humidity: There is a level of Environmental Moisture Content, EMC, consistent with maximum chemical, physical, or biological stability. When the EMC is too low or too high, the associated relative humidity becomes a risk factor. Therefore, it is of prime importance to control the surrounding relative humidity within acceptable limits in order to minimize risk associated with moister levels (Figure 1).

Temperature: Temperature is a very critical factor because of chemical changes which occur when temperature becomes too low or too high. Thermal energy not only accelerates aging, but also can magnify the effects of incorrect relative humidity. The American Society of Heating, Refrigeration, and Air-Conditioning Engineers (ASHRAE) have published recommended standards for thermal comfort parameters. Maintaining a building within the following ranges of temperature and relative humidity will satisfy the thermal comfort requirements of most occupants. It's very important to control room temperature to avoid its bad effect.

Illumination intensity: Overexposure to light can cause photochemical or photo physical changes for some materials. But it
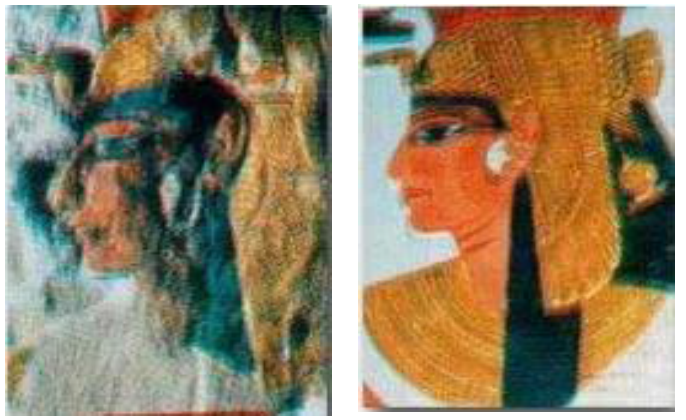

Figure 1: Effect of moisture content in the colour of artifacts.

\begin{tabular}{|l|c|c|c|c|c|}
\hline \multirow{2}{*}{ Species } & \multicolumn{2}{|c|}{ Optimum } & \multicolumn{3}{c|}{ Limits } \\
\cline { 2 - 6 } & ${ }^{\circ} \mathrm{C}$ & $\mathrm{RH}$ & ${ }^{\circ} \mathrm{C}$ & ${ }^{\circ} \mathrm{C}$ & $\mathrm{RH}$ \\
\hline Aspergillus asmteelodami & 33 & $93 \%$ & 10 & 42 & $71 \%$ \\
\hline A. niger & 33 & $>98 \%$ & 12 & 43 & $78 \%$ \\
\hline A. Gumigatus & 40 & $>97 \%$ & 12 & 53 & $82 \%$ \\
\hline Penicillium matensil & 23 & $>98 \%$ & $<5$ & 32 & $79 \%$ \\
\hline P. islandicum & 31 & $>97 \%$ & 10 & 38 & $83 \%$ \\
\hline Stackybotrys atra & 23 & $>8 \%$ & 7 & 37 & $94 \%$ \\
\hline
\end{tabular}

Table 1: Mold temperature and moisture relationship from ASHRAE. may be controlled by architectural, to design the lighting source out of exposure to artifacts [7-10].

Biological attacks (pests): It includes some insect species, mold, fungi and bacteria, controlling of relative humidity and ventilation can control it, the fungi activity can be limited by reducing relative humidity levels. The fungi activity is demonstrate in Valley of the Kings, this activity has led to undesirable effect such as the figure shown below on the tomb wall paintings. Most molds thrive at warmer temperatures. When combined with high levels of Humidity (about $70 \%$ or higher), temperatures of 22 to $24^{\circ} \mathrm{C}$ can cause mold to develop as shown in the (Tables 1 and 2) below. One of the primer motivator for this study was to be able to control the biological activity via ventilation to reduce the relative humidity levels.

The consequences from biological attacks and pest infestation can be described clearly in Figures 2 and 3.

Vibration: Vibration which transmitted from motors, compressors, tourist busses, seismic shocks and the wind can cause damage to sensitive objects. We should be more careful for the risk of vibration transfer through ductwork to works hung on adjacent walls or in particularly active air drafts [11].

\section{Main factors affecting human comfort}

Human comfort is a very important issue to study; it is affected by:

1. Temperature,

2. Relative humidity,

3. Local air speed.

The above parameter can be controlled and it is affected also by health, age, activity, clothing, sex, food, location, season, etc. ASHRAE standard 55-2013 Thermal Environmental Conditions for Human Occupancy sets several principles that must be accomplished by the air distribution system.. Furthermore, the study indicated the need suggests different comfort conditions for Egyptian climate. The human comfort includes Air Quality which influence the term Indoor Air Quality.(IAQ) this term is concern about the air contaminants which includes pollutants and overcrowding, tobacco smoke, microbiological contamination. Any particles 10 microns or less are considered respirable. Generally, the smaller the particle the greater the likelihood for penetrate deeply into the airways $[12,13]$.

\section{Background}

\section{General}

Human comfort and indoor air quality (IAQ) in residential and

\begin{tabular}{|c|c|c|c|c|c|c|c|}
\hline Month & dbt & wbt & dp & rh & epsi & $\mathbf{V}$ & h \\
\hline January, max & 23 & 16.79 & 13.11 & 54 & 9.7 & 0.87 & 47.65 \\
\hline February, max & 26 & 17.77 & 13.06 & 45 & 9.67 & 0.88 & 50.63 \\
\hline Mars, max & 30 & 19.14 & 13.22 & 36 & 9.77 & 0.89 & 54.95 \\
\hline April, max & 35 & 21.91 & 15.75 & 32 & 11.54 & 0.91 & 64.59 \\
\hline May,max & 39 & 22.79 & 15.3 & 25 & 11.2 & 0.92 & 67.81 \\
\hline June, max & 41 & 24.15 & 16.98 & 25 & 12.49 & 0.93 & 73.16 \\
\hline July, max & 41 & 25.09 & 18.79 & 28 & 14.02 & 0.93 & 77.11 \\
\hline August, max & 41 & 25.69 & 19.9 & 30 & 15.05 & 0.93 & 79.75 \\
\hline September, max & 39 & 25.37 & 20.21 & 34 & 15.34 & 0.92 & 78.44 \\
\hline October, max & 35 & 22.89 & 17.61 & 36 & 13.01 & 0.91 & 68.36 \\
\hline November, max & 30 & 21.74 & 18.04 & 49 & 13.37 & 0.9 & 64.16 \\
\hline December, max & 25 & 18.63 & 15.24 & 55 & 11.16 & 0.88 & 53.42 \\
\hline
\end{tabular}

Table 2: Luxor design conditions 


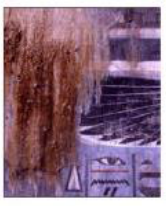

Nest

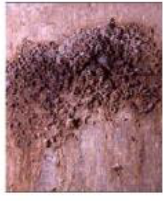

Concretion

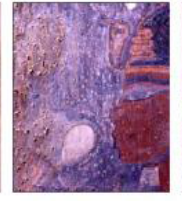

Excrement

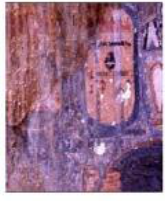

Urine drip

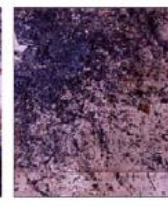

Bacteria
Figure 2: Typology and consequence of biological attacks (bat guano)
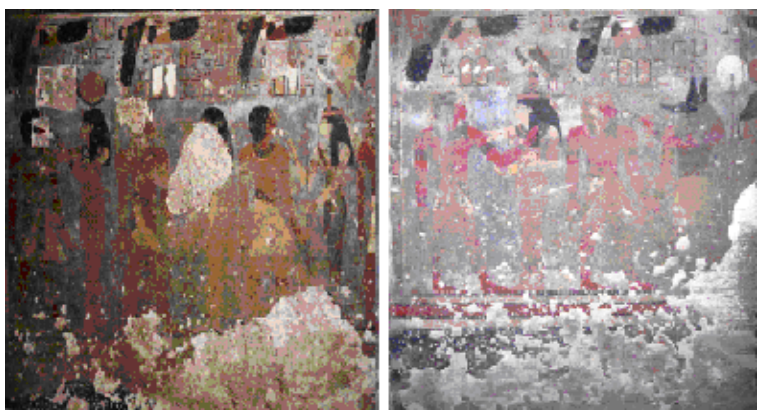

Figure 3: Effect of pest infestation in the wall painting.

commercial application depends on many factors, including thermal regulation, control of internal and external sources of pollutants, supply of acceptable air, removal of unacceptable air, occupants' activities. This part focuses on reviewing the previous thermal comfort experimental and numerical investigations carried out in enclosed spaces reported to provide an overall view of the research status at the commencement of the present work. The major experimental and numerical investigations of airflow characteristics in enclosed spaces are shown here in tabulated form. Comments and assessments follow on such work [14-18].

\section{Ventilation in archaeological tombs of valley of the Kings, Luxor: Omar Abdel-Aziz and Khalil 2005}

This study,published 2005 had focused on the mechanical ventilation systems effect on airflow pattern as well as temperature and relative humidity distribution inside three tombs namely KV1, KV9, and KV62 to design an optimum HVAC airside system that provides comfort and air quality in the air conditioned spaces The study was carried out using computational fluid dynamics (CFD) simulation using a commercial CFD code which solved the continuity, momentum, energy, and species transport equations in addition to k-epsilon model equations for turbulence closure. The SIMPLEC algorithm was used for the pressure-velocity coupling and a second order upwind scheme was use for discretization of the governing equations. Mesh sizes used in the work exceeded 700,000 mesh volumes in one case, and all mesh sizes were above 100,000 mesh volumes. The outside air conditions, number of visitors, and airside system design effect on the tombs' airflow characteristics were studied in order to reach the optimum ventilation design (Table 2 and Annexure 2).

\section{Tomb of Rameses VII (KV1)}

The airflow distribution in its final steady pattern is a result of different interactions such as, the airside design, objects distribution, thermal effects, occupancy movements, etc. The entrance zone is excluded from the tomb structure as it doesn't represent airflow inside enclosure. These volumes are discretized using the tetrahedral tool due the complex geometry inherent in the model. Various mesh sizes could be obtained for each tomb. Different configurations are investigated:

- Either the left or right outlets are enabled while the rest are treated as walls

- The centre floor mounted outlets are enabled while the rest are treated as walls.

- Both the left and right floor mounted outlets are enabled while the centre outlets are treated as walls.

The type of ventilation used: mechanical supply or mechanical extraction or both, effect of the number of visitors on the airflow characteristics are considered. Visitors' bodies and faces are considered as isothermal walls.

\section{General flow pattern}

The general flow pattern was studied via velocity magnitude contour plot for a vertical mid plane along the tomb axis as shown in Figure 4.

\section{Thermal pattern}

Simulating February's maximum air design conditions, shown in Figure 5 indicated a homogeneous temperature distribution throughout the tomb. On the other hand, in case of simulating August's maximum air design conditions, showed larger temperature variations inside the tomb Hence, The tombs should be closed in cases of such harsh conditions in order to keep the tombs well preserved.

It was found that the temperature gradient near the walls is almost similar in all cases. On the other hand, the mechanical supply ventilation system provided better thermal distribution in the occupation zone $[19,20]$.

\section{Relative humidity patterns}

It was assured that the higher the number of visitors inside the tomb, the larger the wall portion that is subjected to $\mathrm{RH}$ values higher than $60 \%$. The results for no visitors inside the tomb showed higher $\mathrm{RH}$ values only due to the absence of internal heat loads and hence lower airflow temperatures as shown in Figure 6.

\section{Rameses V and Rameses VI (KV9)}

The general flow pattern inside KV9 tomb is affected by the airside system design as shown in Figure 7 where the extraction air outlets' location has a considerable effect on the main flow pattern; case 1 resulted in larger velocity magnitude until the first burial zone. Furthermore, case 2 resulted in a similar situation but the airflow velocity beyond the first burial zone is decreased (Figure 7).

It should be noted that the increased number of visitors inside the tomb resulted in increased velocities inside the tomb as the visitors are considered as obstacles for the airflow.

\section{Relative humidity pattern}

The relative humidity distribution inside KV9 tomb indicated the superiority of the mechanical extraction ventilation system over the mechanical supply; especially through centrally located air outlets as shown in Figure 8 below.

\section{Tutankhamen (KV 62)}

The structure of KV62 is quite different from that of KV1 and KV9. Hence, the proposed airside system design relied mainly on fixed air grills locations. It is shown that if mechanical supply system is used higher air velocities are experienced near the walls which are unacceptable as it 
Citation: Khali EE (2017) On the Modeling of Air Flow in the Tombs of the Valley of Kings. Fluid Mech Open Acc 4: 166. doi: 10.4172/24762296.1000166
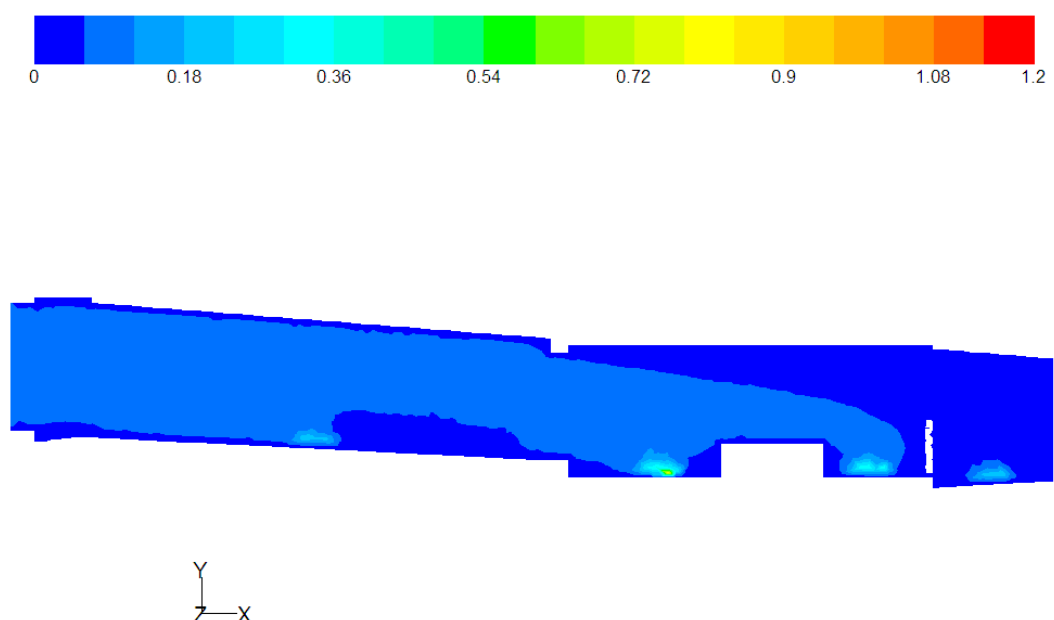

Figure 4: Velocity magnitude contours for a mid-plane along KV1 tomb axis.
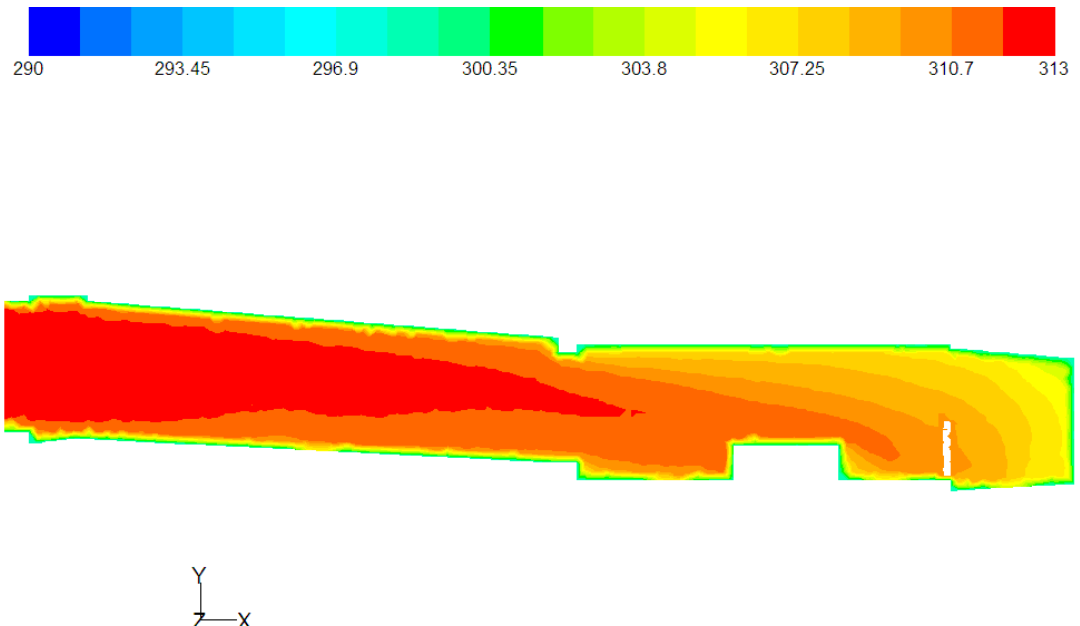

Figure 5: Temperature contours for a mid-plane along KV1 tomb axis.
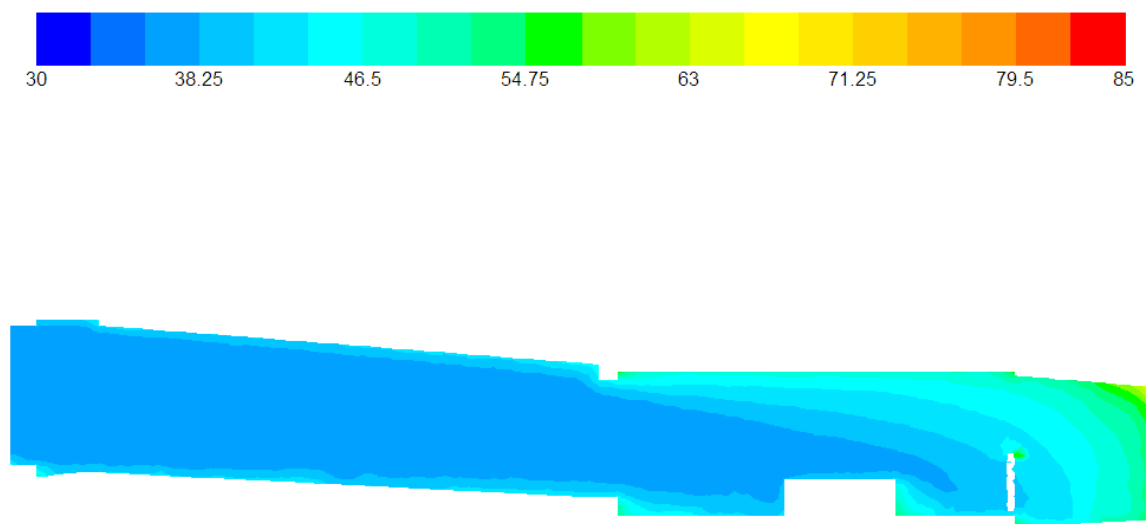

Figure 6: $\mathrm{RH}$ contours for a mid-plane along KV1 tomb axis.

exceeded the recommended velocity of $0.12 \mathrm{~m} / \mathrm{s}$. The temperature and relative humidity distribution presented assure that the mechanical extraction ventilation system provides better distribution; however, still it resulted in excessive humidity inside the side rooms. Also the number of visitors' effect was clearly identified, showing better performance with the lower number of visitors, 17 visitors, as shown in Figure 9. 
Citation: Khalil EE (2017) On the Modeling of Air Flow in the Tombs of the Valley of Kings. Fluid Mech Open Acc 4: 166. doi: 10.4172/24762296.1000166
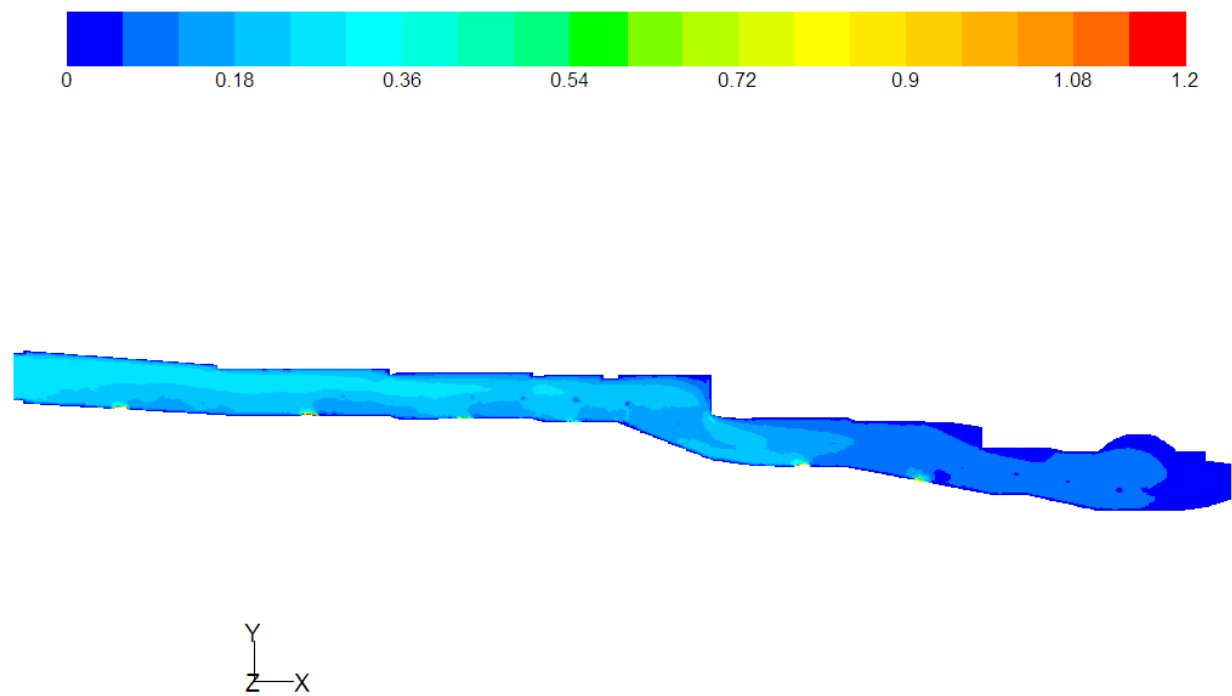

Figure 7: Velocity magnitude contours for a mid-plane along the KV9 tomb axis.

\begin{tabular}{|l|l|l|l|l|l|l|}
\hline & & & & & & \\
\hline
\end{tabular}
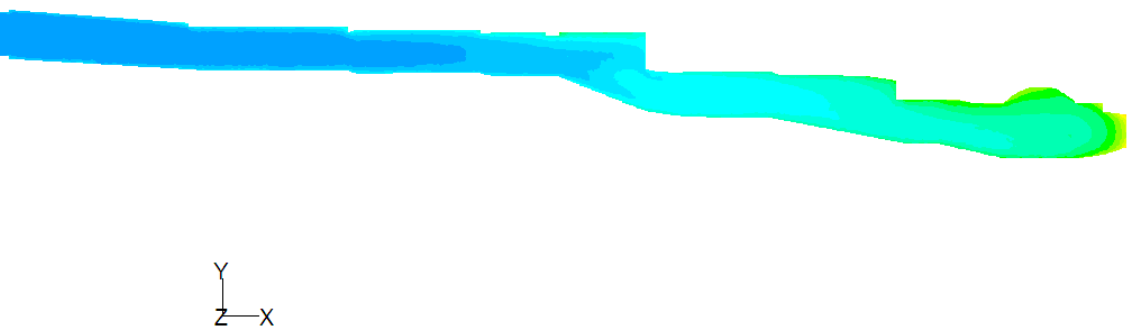

Figure 8: RH contours for a mid-plane along KV9 tomb axis.
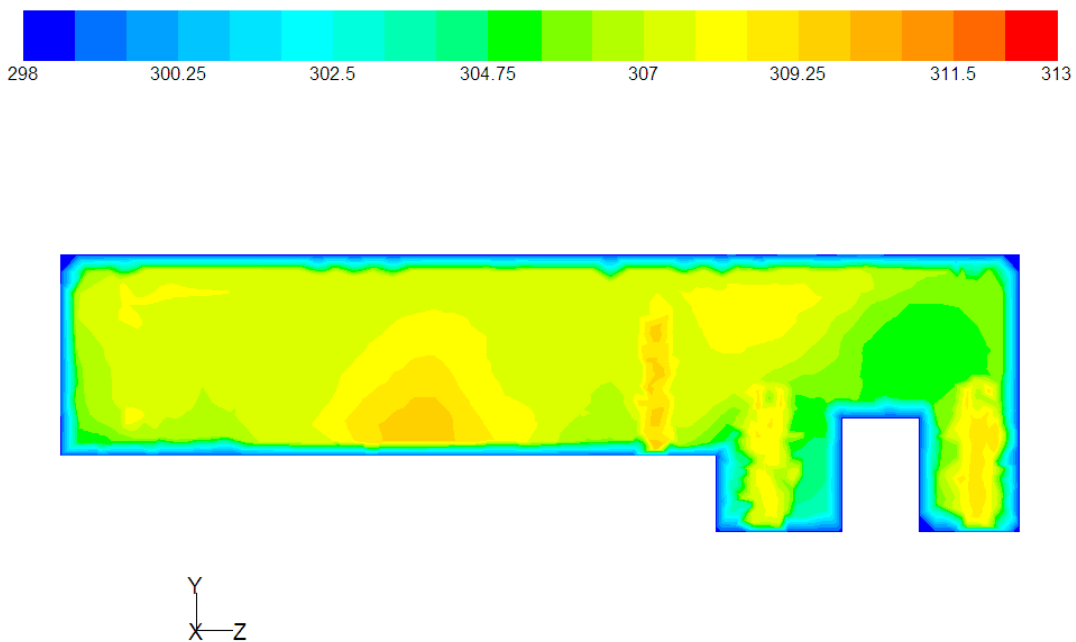

Figure 9: Temperature contours for transverse plane at $\mathrm{x}=18.5 \mathrm{~m}$ (KV62) 


\section{Thermal pattern}

Finally it was found that the main flow pattern of the free supplied air and floor mounted extracts is slightly influenced by the extraction ports locations. For each visitor group location, a corresponding proper airside design is suggested to provide the optimum utilization of the supplied air. The optimum utilization of the air movement to ventilate and reduce temperature can be attained by locating the extraction ports to minimize the recirculation zone and prevent the air short circuits. Ideally, the optimum airside design system can be attained, if the airflow is directed to pass all the enclosure areas before the extraction [21-25].

\section{H.M. Ezz Eldin and Khalil 2006}

Thermal comfort prediction and assessment in ventilated archaeological tombs, Kings Valley, Luxor. This work investigates the human thermal comfort inside the three tombs KV1, KV9, and KV62 in VALLEY OF THE KINGS, LUXOR for different proposed mechanical ventilation configurations. As tomb KV62 (Tutankhamen) the study has been focused on KV62. The number of visitors, outside air conditions, and different mechanical ventilations configurations were studied for the three tombs using FLUENT ${ }^{\oplus}$ 6.2 CFD (Computational Fluid Dynamics) package The study is a supplement the work of Omar A. Aziz with addition of thermal comfort prediction which based on the PMV (Predicted Mean Vote) model and the PPD (Percentage Predicted Dissatisfied) model to apply these factors in the design of ventilation system. The PMV equation contains many parameters which should be defined such as, the metabolic rate, mechanical work, the clothes insulation, the coefficients of heat transfer, and others in order to be able to calculate mesh sizes exceeded 1,400,000 mesh volumes in one case, and all mesh sizes were above 100,000 mesh volumes [26-30].

This work took into consideration the terms of human comfort such as internal Heat Production (Metabolic rate, Mechanical power), The Sensible and latent heat dissipated from skin and. Evaporative heat loss from skin and Respiratory losses. The visitors' body and visitors' face are treated as a wall at a constant temperature. Finite volume mesh used through this work was of the tetrahedral type. The thermal load equation is plugged into FLUENT ${ }^{*}$ by means of Custom Field Function where the values of $t_{a}$ and $h_{c}$ are determined from the CFD results, and. Similarly, the PMV and PPD where defined in FLUENT ${ }^{\circ}$, and then calculated and displayed (Annexure 2).

\section{Rameses VII (KV 1)}

Depicting the effect the outside air condition, four cases has been carried out simulating the four months August, September, October, and February respectively with different dry bulb temperature and humidity and constant number of visitors and mesh size. Kinetic energy and thermal pattern has been investigated also. The temperature contours, (Figure 10), for the cases depict the great effect the outside air condition has on the temperature patterns inside the tombs [31-33].

\section{Relative humidity}

The relative humidity is shown in Figure 11 for Case 2 that indicated the highest relative humidity that reaches $68 \%$, which support the growth of the fungi and mold on walls, ruin the paintings, and spoil the colours (Figure 11).

\section{PMV and PPD patterns}

Figures 12 and 13 demonstrated the PMV variation and PPD for the tomb of Ramses known as KV1.

\section{Rameses V and Rameses VI (KV9)}

The construction of KV-9 is a single axis tomb, $116.84 \mathrm{~m}$ long and $4 \times 4 \mathrm{~m}$ cross section with intermediate and end halls different cases was investigated with different mesh size and number of visitors with constant inlet Rh and DBT. The corresponding thermal pattern is shown in Figure 14 and the predicted PMV contours are shown in Figure 15 for KV9.

\section{Thermal patterns}

The contour plots showed that the mass flow rate has a significant effect of relative humidity all through the tomb. As for the increase of mass flow rate,the average relative humidity decreased, for case 1 the relative humidity reached more than $80 \%$

\section{Tutankhamen (KV 62)}

Three different mesh sizes were used to simulate one case for the KV 62 tomb, one grid of less than 200000 tetrahedral mesh volume were used for preliminary investigation, while the second grid of more than 600000 mesh volumes could be used as a typical grid, and the third grid is more than 1.6 million mesh. The velocity near walls should not exceed $0.12 \mathrm{~m} / \mathrm{s}$ (1) in order not to create any undesired effects on the paintings. Relatively high temperature gradient reaches $9{ }^{\circ} \mathrm{C}$ near walls can be noticed, leading to thermal gradients.

It has been noticed the increase in the relative humidity as the visitors' number increase reaching $66 \%$ as indicated in Figure 16, while
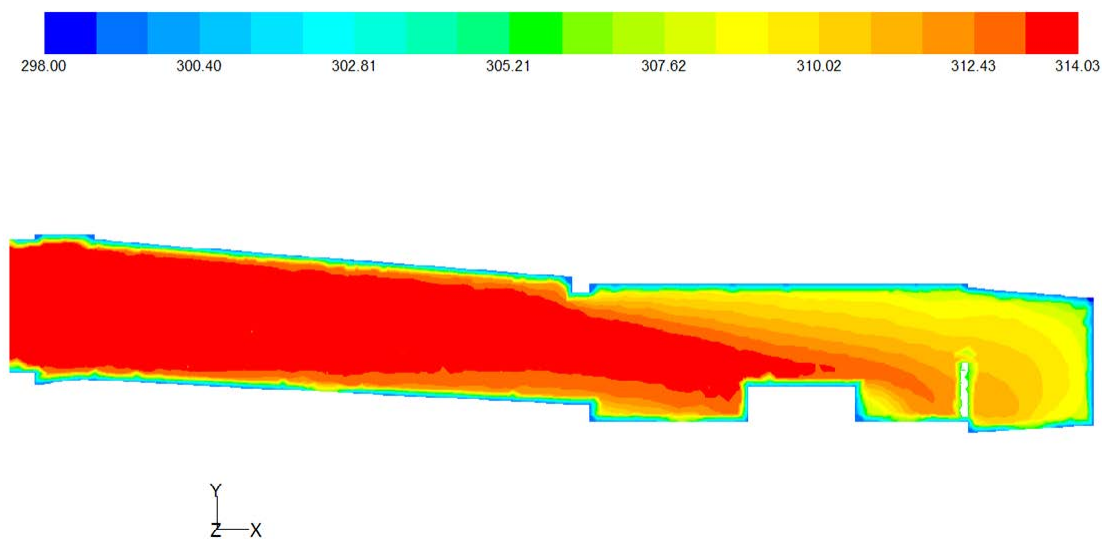

Figure 10: Temperature contours for mid plane, $z=1.8 \mathrm{~m}, \mathrm{KV} 1$. 
Citation: Khali EE (2017) On the Modeling of Air Flow in the Tombs of the Valley of Kings. Fluid Mech Open Acc 4: 166. doi: 10.4172/24762296.1000166
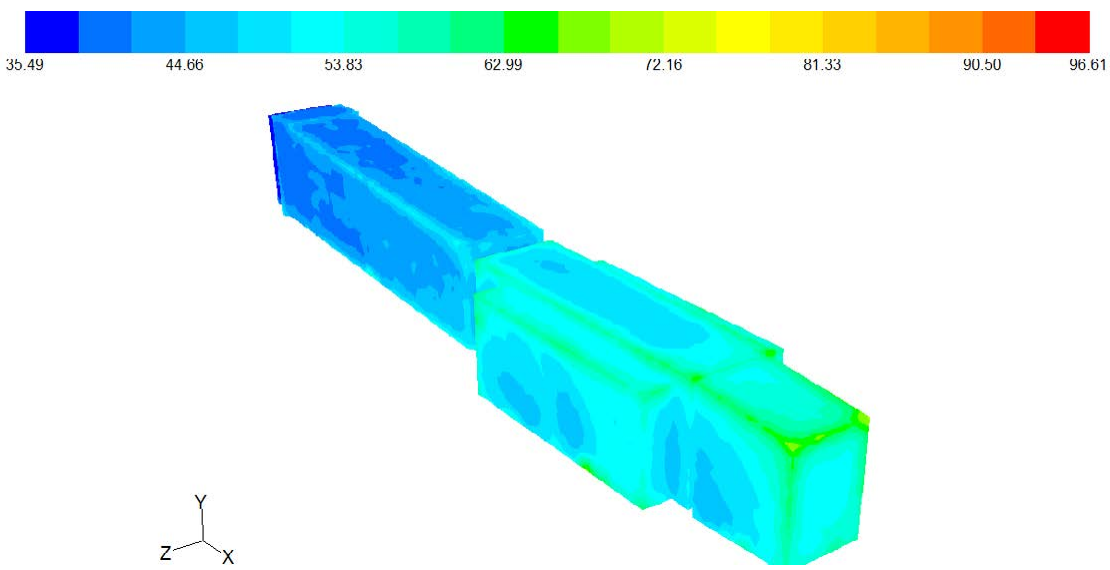

Figure 11: Relative humidity Contours at walls, KV 1 (Case 2).
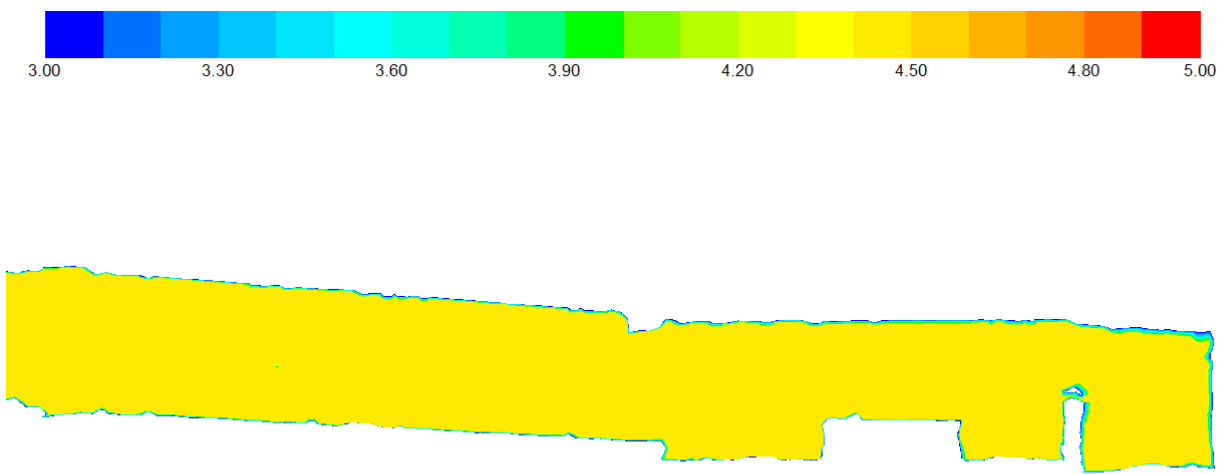

$Y-x$

Figure 12: PMV contours for a mid-plane at $z=1.8 \mathrm{~m}, \mathrm{KV} 1$.

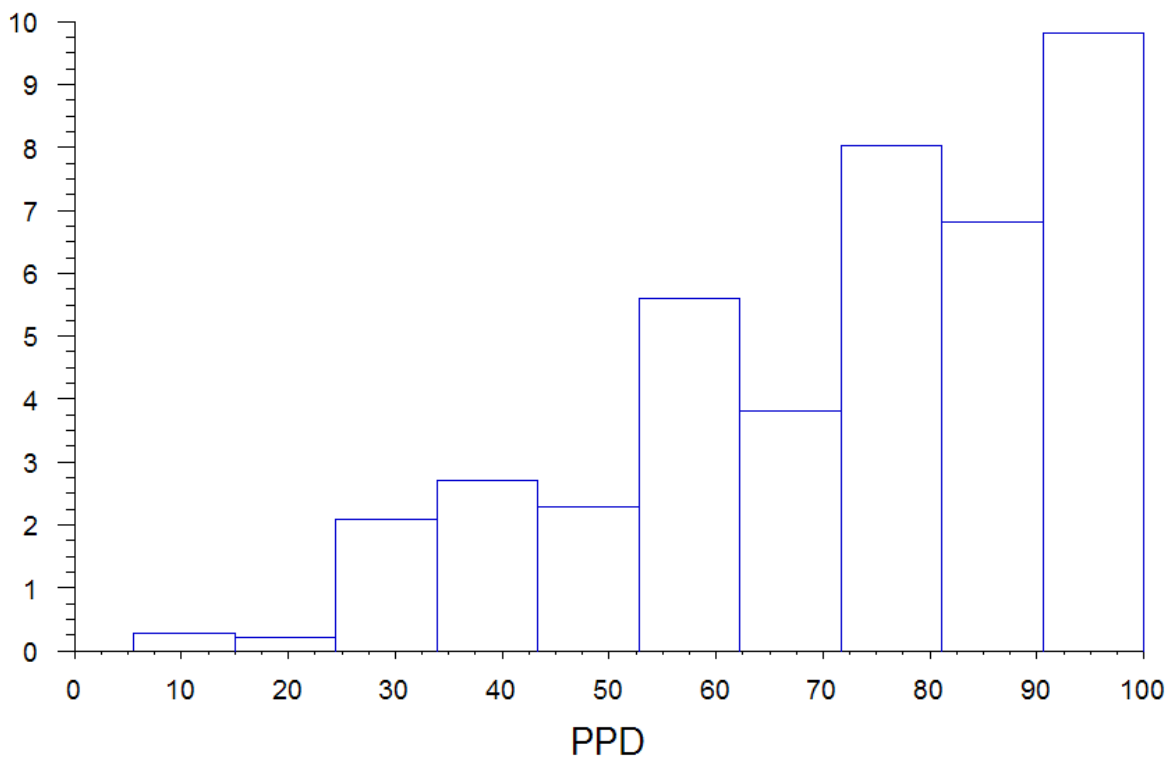

Figure 13: PPD histogram for KV1. 
Citation: Khalil EE (2017) On the Modeling of Air Flow in the Tombs of the Valley of Kings. Fluid Mech Open Acc 4: 166. doi: 10.4172/24762296.1000166
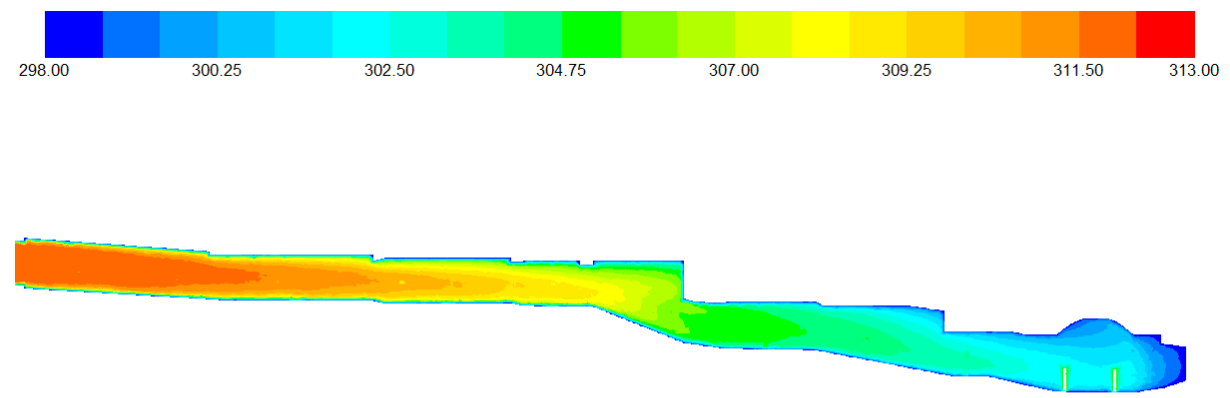

$Y-x$

Figure 14: Temperature contours for a middle plane, KV 9 Case 1.
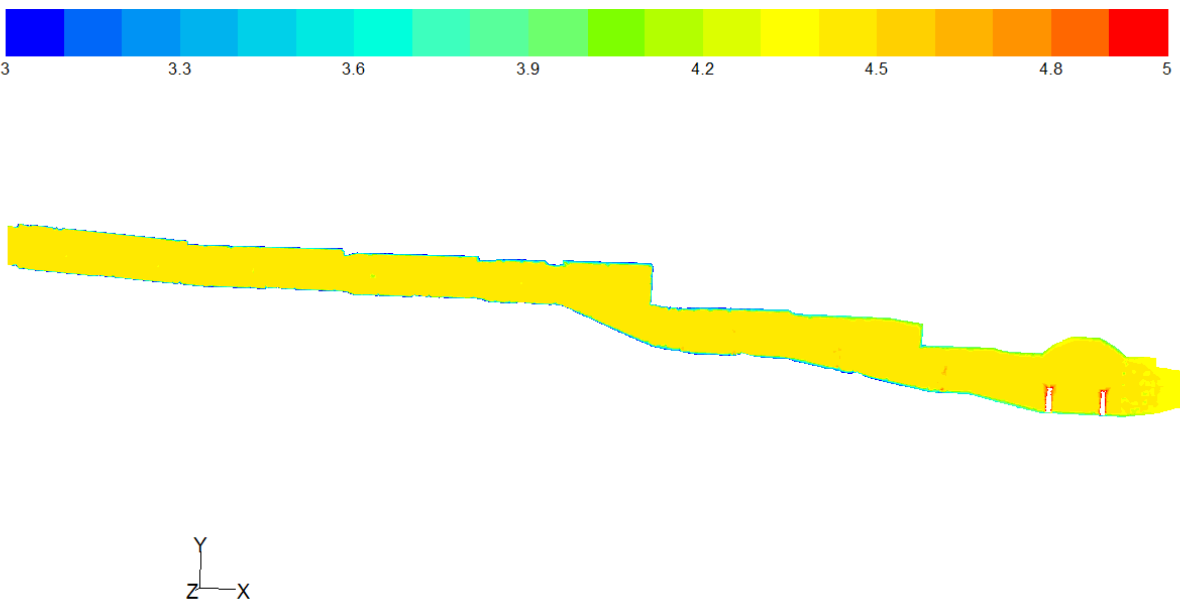

Figure 15: PMV Contours for Dissatisfied Visitors, KV 9 case1.
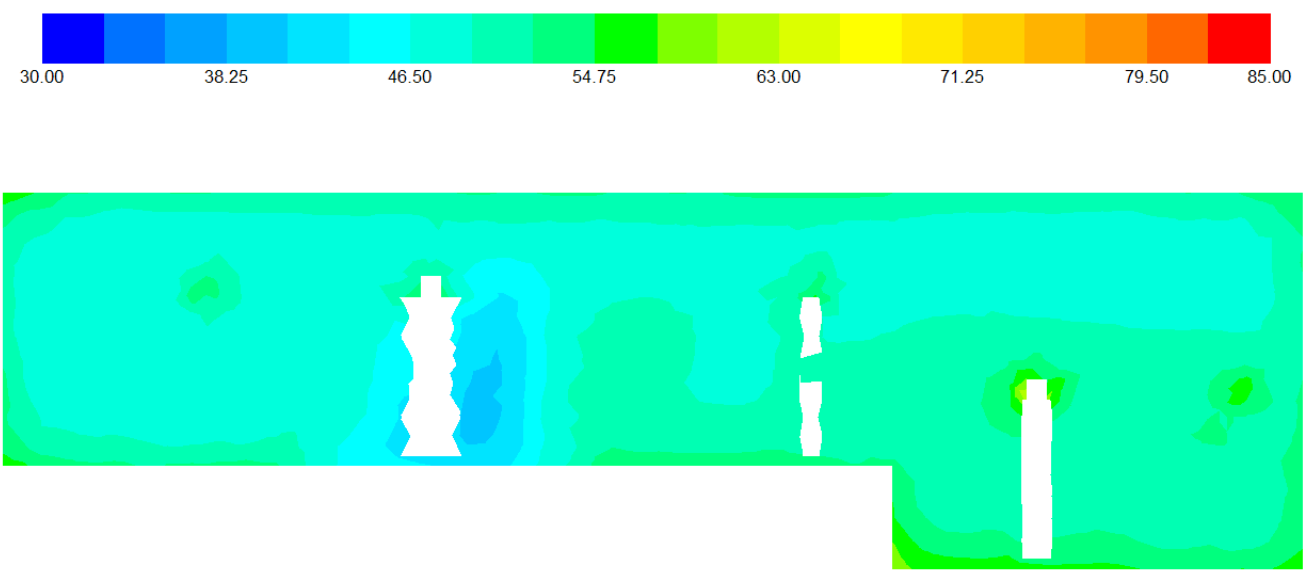

$Y-Z$

Figure 16: Relative humidity contours for transverse plane $x=17 \mathrm{~m}, \mathrm{KV}-62$ Case 1. 
Citation: Khalil EE (2017) On the Modeling of Air Flow in the Tombs of the Valley of Kings. Fluid Mech Open Acc 4: 166. doi: 10.4172/24762296.1000166

Page 9 of 20

Figure 17 demonstrated the predicted PMV contours.

Figure 18 demonstrated the level of details in predicting the flow patterns in a vertical section of the tomb descending corridor to the sarcophagus [34].

The penetration decrease as the visitors' number increase as they perform as an obstacle for the outside air depict the high temperatures gradient near walls leading to high thermal gradients.

\section{Present Design Methodology}

\section{General}

The present work we have to investigate numerically airflow pattern, kinetic Energy, and temperature and relative humidity distributions inside the archaeological tombs of the Kings in King Valley, Thebes to determine the effect of geometrical shape on the flow.

\section{Classification of tombs}

The geometrical shape of the tomb according to number of passages can be classified into:

${ }^{\star}$ Single (simple) passage.
${ }^{\star}$ Multi (complicated) passages.

In this study we choose single passage tomb with more than one room in burial zone.

Four different tombs were selected according to single passage:

Rameses VII (KV1) (tomb data taken from (www.KV5.com): Rameses VII tomb, KV1 is located in Valley of the Kings, Thebes. The entrance is cut into the base of a hill at the end of the first northwest branch Wadi (Valley). This unfinished tomb comprises an open entryway ramp (A), corridor (B), vaulted burial chamber (J), and an unfinished chamber $(\mathrm{K})$ with a rear recess as can be shown in Figure 19 below. The walls are decorated with excerpts from the "Book of the Gates" (chamber K), "Book of Caverns" (corridor B), "Book of the Earth" (burial chamber J), "Opening of the Mouth ritual" (corridor $\mathrm{B}$ ), and the deceased with deities (corridor B, chamber $\mathrm{K}$, burial chamber J) the ceilings are painted with motifs of flying vultures and astronomical figures. There are 135 Greek, and several demotic, Coptic, and nineteenth century graffiti in the tomb, indicating that KV 1 has been accessible since antiquity. KV1 tomb is considered as a single straight axis tomb oriented toward northwest. The site is located at 25.44 North Latitude and 32.36 East Longitude. The tomb is $171.219 \mathrm{~m}$
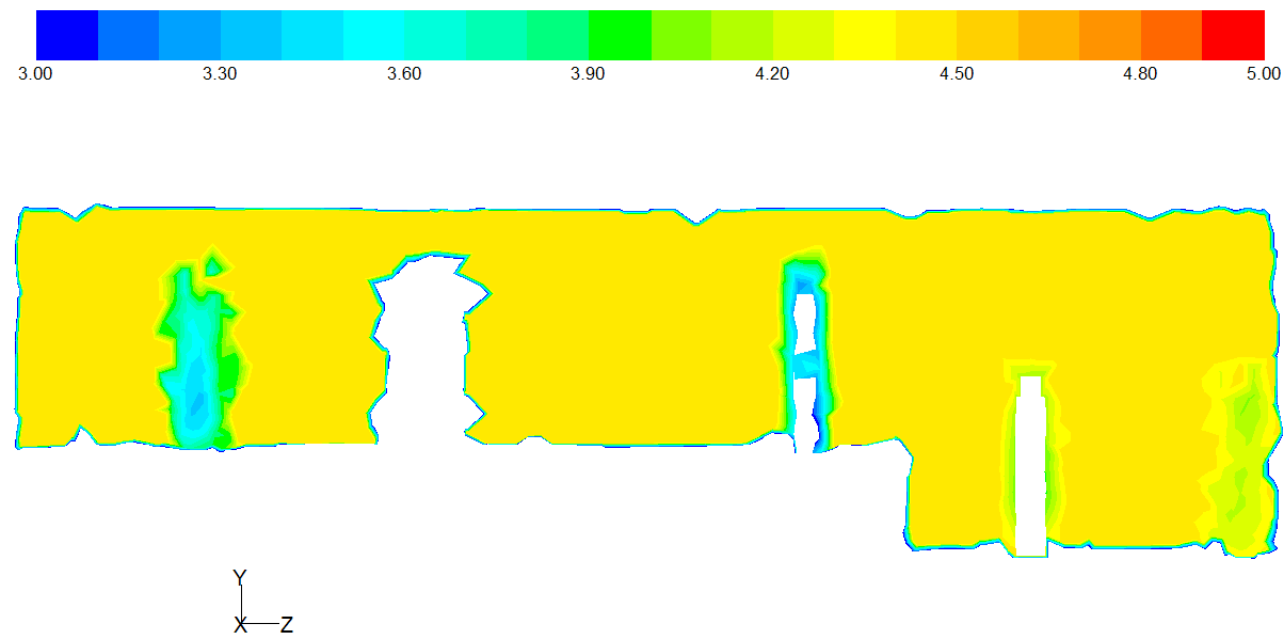

Figure 17: PMV contours for a transverse plane $x=17 m, K V 62$ case 1 .

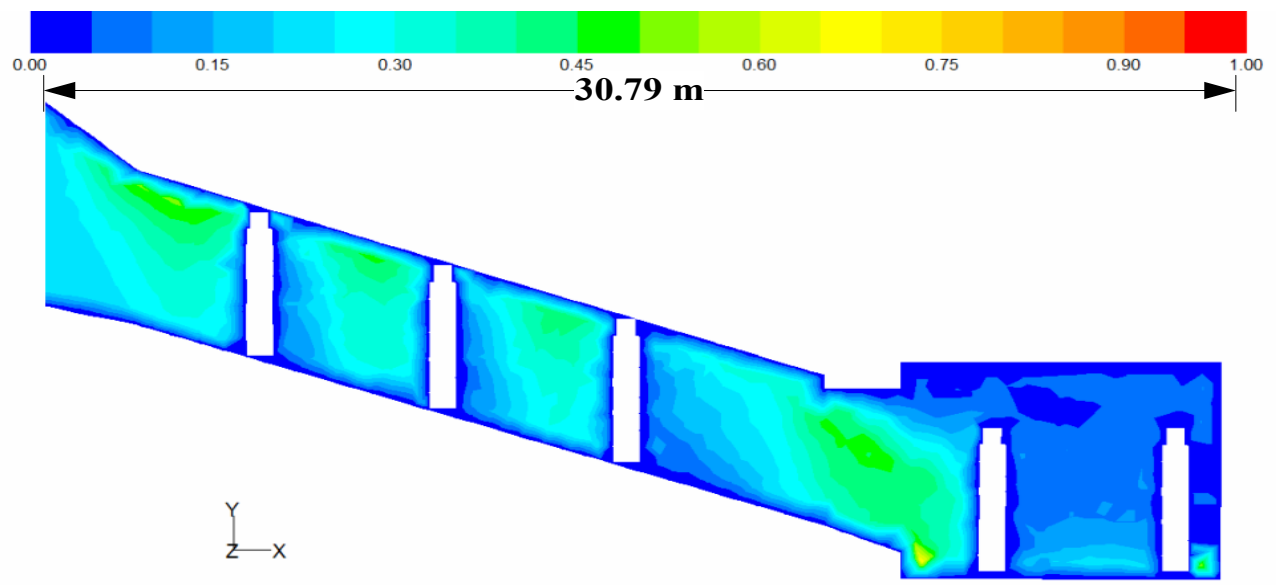

Figure 18: Velocity magnitude contours, m/s, for longitudinal plane $z=-1.5 \mathrm{~m}, \mathrm{KV} 62$. 
Citation: Khalil EE (2017) On the Modeling of Air Flow in the Tombs of the Valley of Kings. Fluid Mech Open Acc 4: 166. doi: 10.4172/24762296.1000166

above sea level. The maximum height is $4.25 \mathrm{~m}$; minimum width is 2.74 $\mathrm{m}$, while the maximum width is $5.17 \mathrm{~m}$. The tomb total length is 44.3 $\mathrm{m}$. The floor area is measured to be $163.56 \mathrm{~m}^{2}$, while the total volume is $463.01 \mathrm{~m}^{3}$, (Figure 19).

Ramesses IV (KV2), tomb data taken from (www.KV5.com): Found in the Valley of the Kings, is the tomb of Rameses IV, and is located low down in the main valley, between KV7 and KV1. It has been open since antiquity and contains a large amount of hieratic graffiti. The tomb is mostly intact and is decorated with scenes from the Litany of Ra, Book of Caverns, Book of the Dead, Book of Amduat and the Book of the Heavens. The sarcophagus is broken (probably in antiquity), and the mummy was relocated to the mummy cache in KV35.

$\mathrm{KV} 2$ is cut into the base of a hill on the northwest side of the main wadi of the Valley of the Kings, just south of the branch wadi leading to $\mathrm{KV} 1$. The tomb consists of three gently sloping corridors $(\mathrm{B}, \mathrm{C}, \mathrm{D})$ followed by a chamber (E), a burial chamber (J), and a corridor beyond (K) with side chambers Ka-c. The tomb is decorated with scenes from the Litany of Ra (corridor B, corridor C), Book of Caverns (corridor D, corridor K), Book of the Dead (well chamber E), Book of Gates (burial chamber J), Imydwat (burial chamber J), Book of Nut (burial chamber $\mathrm{J}$ ), Book of the Night (burial chamber J), Book of the Earth (gate $\mathrm{Kb}$ ), deceased and deities (corridor B, corridor $\mathrm{K}$, side chamber Ka, side chamber $\mathrm{Kb}$, side chamber $\mathrm{Kc}$ ), and burial furniture (side chamber $\mathrm{Kb}$ ).

The original plan of the tomb was altered after the death of the king, and the chamber which would have been pillared chamber $\mathrm{F}$ was used for burial chamber J. Two plans of the tomb are known: a plan of the whole tomb drawn on a papyrus now in the Turin Museum (Cat. 1885), and a sketch of the doorway of the tomb on an ostracon found in the rubble at the entrance. Noteworthy features: Notable architectural

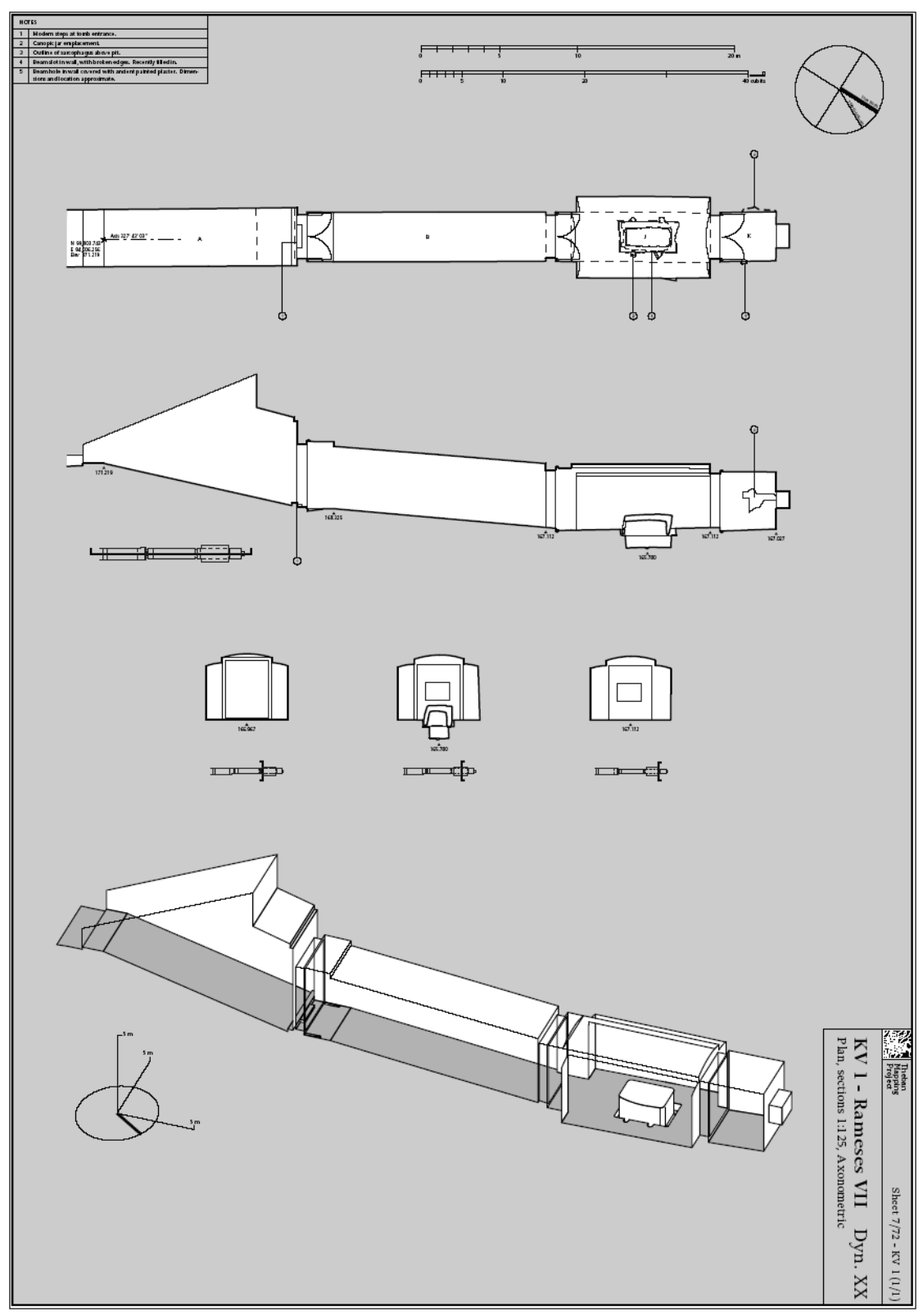

Figure 19: KV1 schematics (www.KV5.com). 
features of this tomb include: the barrel-vaulted ceiling of corridor D; the ramp through the floor of corridor $\mathrm{D}$, gate $\mathrm{E}$ and chamber $\mathrm{E}$; the conversion of a pillared chamber into a burial chamber; side chambers and recesses off the rear corridor $\mathrm{K}$. Also unusual are the number of foundation deposit pits, although not all were used. Decoration unique to this tomb includes the representation of Shu and Nut from the Book of Nut on the ceiling of burial chamber J, the mummiform figures in Ka and Kc, and parts of the Book of Caverns, which appear for the first time in the Valley of the Kings. KV 2 is one of the few tombs for which an ancient plan has survived. The tomb was frequently visited in antiquity, and graffiti are scattered throughout the tomb. In general, each visitor left his name, his profession, his origin, and personal comments about the tomb. There is a significant number of Coptic graffiti, including representations of saints and Coptic crosses. The tombs Maximum height: $5.21 \mathrm{~m}$ and Minimum width: $1.24 \mathrm{~m}$ and Maximum width: 8.32 $\mathrm{m}$ and Total length: $88.66 \mathrm{~m}$ and Total area: $304.88 \mathrm{~m}^{2}$ while the Total volume is: $1105.25 \mathrm{~m}^{3}$ (Figure 20).

The tomb of Bay (KV13) tomb data taken from (www.KV5. com): Located in the Valley of the Kings in Egypt, was used for the burial of the noble Bay of the Nineteenth Dynasty. It was later reused by Amenherkhepshef and Mentuherkhepsef of the Twentieth Dynasty The tomb of Bay is situated at the end of the southwest branch of the southwest wadi, close to the tombs of Seti II, Tausert and Siptah. The architecture and decoration closely resemble that of the tomb of Queen Tausert. It consists of three corridors (B, C, D) followed by two chambers (E, F), two further corridors $(G, H)$, two side chambers off the second (Ha-b), and a burial chamber (J). The tomb has suffered structural damage from floods, and all the ceilings of the tomb have collapsed. The walls were probably decorated originally with painted plaster and relief. Severe floods have caused the loss of the plaster, however, and now only traces of decoration remain in places where the artist was working on thin plaster and the chiselling cut into the bedrock. The remaining decoration echoes that in KV 14 and represents the deceased with deities (corridor B, corridor D) and parts of the Book of the Dead (corridor C). Noteworthy features: This is one of the rare non-royal tombs cut in the Valley during Dynasty 19. The tomb also demonstrates the late Rameside practice of re-using abandoned tombs for the burial of royal family members, containing two sarcophagi from this period. The tombs Height: $2.53 \mathrm{~m}$ and Width: $5.1 \mathrm{~m}$ and Length: $5 \mathrm{~m}$ and Area: $20.87 \mathrm{~m}^{2}$ and its total Volume is: $54.23 \mathrm{~m}^{3}$ (Figure 21).

The tomb of Seti II KV15, tomb data taken from (www.KV5. com): KV15, the tomb of Seti II, has been known since antiquity and must have lied open during most of the classical period, judging from the 59 Greek and Latin graffiti found on its walls. The tomb was investigated superficially by Pococke, along with others who followed after him. However, it was Howard Carter who cleared most of the tomb between 1903 and 1904, though apparently the ritual well was never excavated. One may find the entrance to KV15, rather than having steps cut below a retaining wall, directly quarried into the base of an almost vertical cliff face at the head of the wadi running south

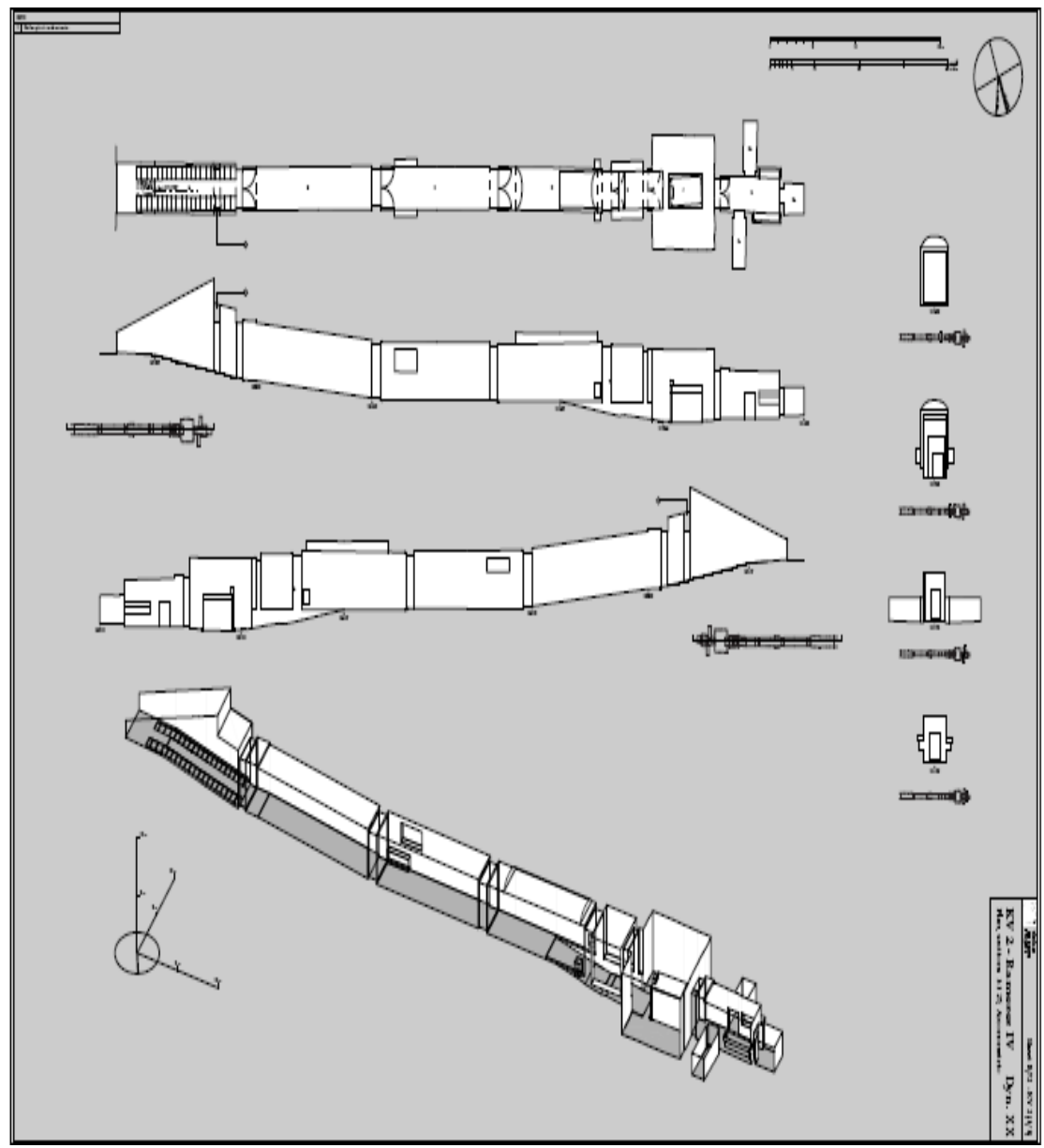

Figure 20: KV2 schematics, (www.KV5.com). 
Citation: Khalil EE (2017) On the Modeling of Air Flow in the Tombs of the Valley of Kings. Fluid Mech Open Acc 4: 166. doi: 10.4172/24762296.1000166

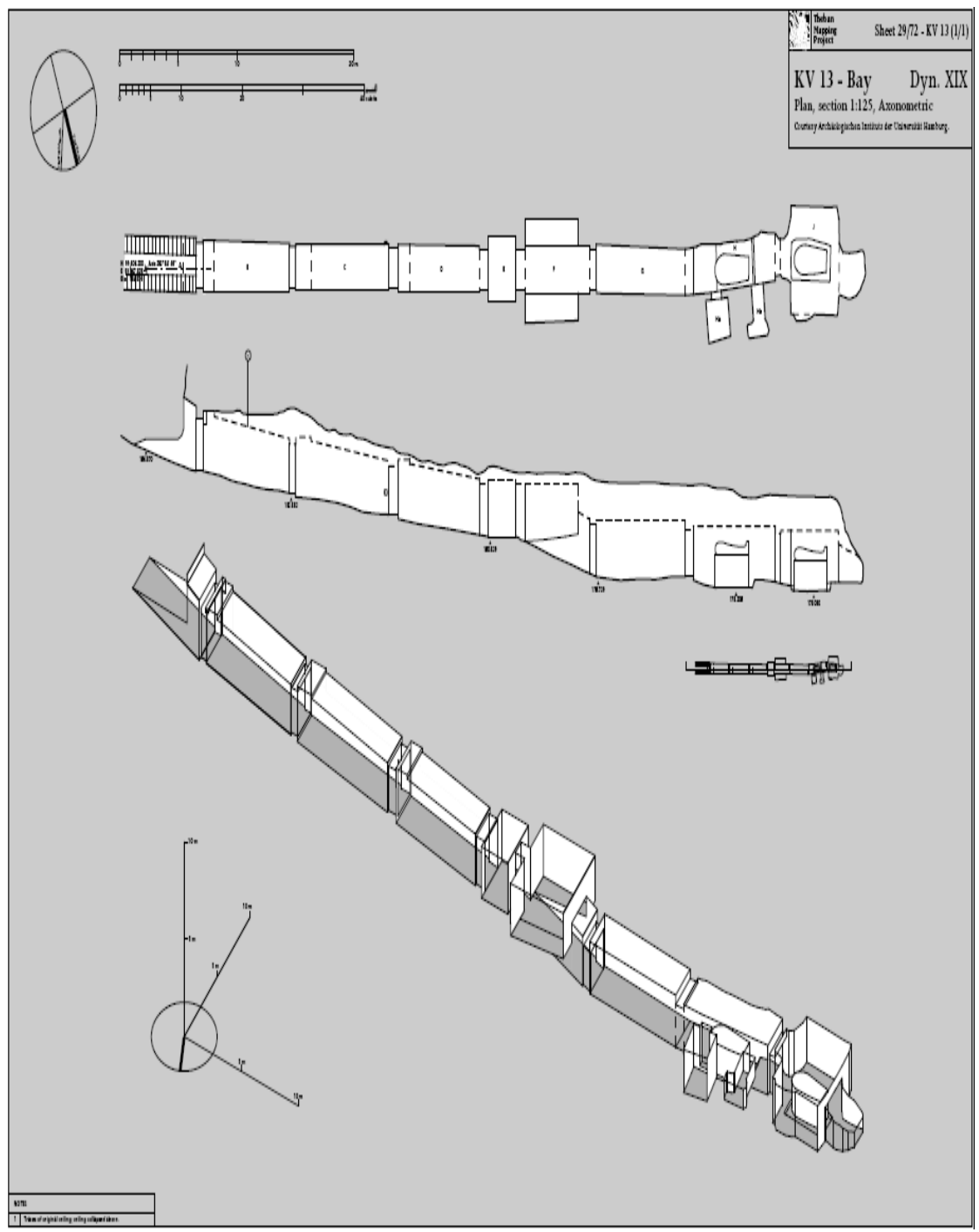

Figure 21: KV13 schematics, (www.KV5.com)

west from the main Valley of the Kings on the West Bank at Luxor (ancient Thebes). However, at present the tomb has been temporarily closed to allow the installation of new flooring, hand rails and lighting. It is expected to soon. The history of the tomb is really unknown at this time. It is very likely that Seti II may have originally been buried with his wife, Tausret, in her tomb and later moved to this tomb which appears to have been hastily and incompletely finished, by Sethnakht (Setakht). In fact, the tomb may have originally been started for Seti II but the work interrupted at some point. This may have had to do with the reign of Amenmeses, if that king ruled concurrently with Seti II rather than before him. It appears that within the tomb, Seti's name was carved, erased, and then carved out once again. The erasure may be attributable to Amenmeses, or possibly to Saptah. It has been suggested that his wife Tausert then had her husband's name restored. The tomb, which takes a Northwest to Southeast axis, consists of a short entryway corridor followed by three long corridors in turn followed by a well room. The well room then communicates with a four pillared hall and then a makeshift burial chamber, formed from what would have been another corridor, where the king's sarcophagus was located. This corridor was hastily converted to a burial chamber at the time of Sety II's death. It's rough walls and ceiling were coated with plaster and decorated with paint. On the walls, the tombs Height: $3.25 \mathrm{~m}$ and Width: $2.77 \mathrm{~m}$ and Length: $8.04 \mathrm{~m}$ the Area: $21.51 \mathrm{~m}^{2}$ and total Volume is: $63.54 \mathrm{~m}^{3}$. Anubis jackals on shrines and two rows of deities representing the followers of $\mathrm{Ra}$ and Osiris are placed over a lower register of prone mummiform figures on snake beds taken from the fifth division (p)/sixth hour (H). A figure of Nut with down swept wings stretches along the length of the ceiling and traces of what may be the ba of $\mathrm{Ra}$ is painted above her head (Figure 22).

The present approach made use of FLUENT' 6.2 commercial codes made available to FECU. The numerical model included the following governing equations:

- Viscous, $\mathrm{k}-\varepsilon$ model or LES,

- Energy,

- Species.

In order to construct the tetrahedral finite volume mesh the preprocessing was carried using mesh generator. It should be noted here that the entry zone is excluded from the numerical model as it is not 
Citation: Khalil EE (2017) On the Modeling of Air Flow in the Tombs of the Valley of Kings. Fluid Mech Open Acc 4: 166. doi: 10.4172/24762296.1000166

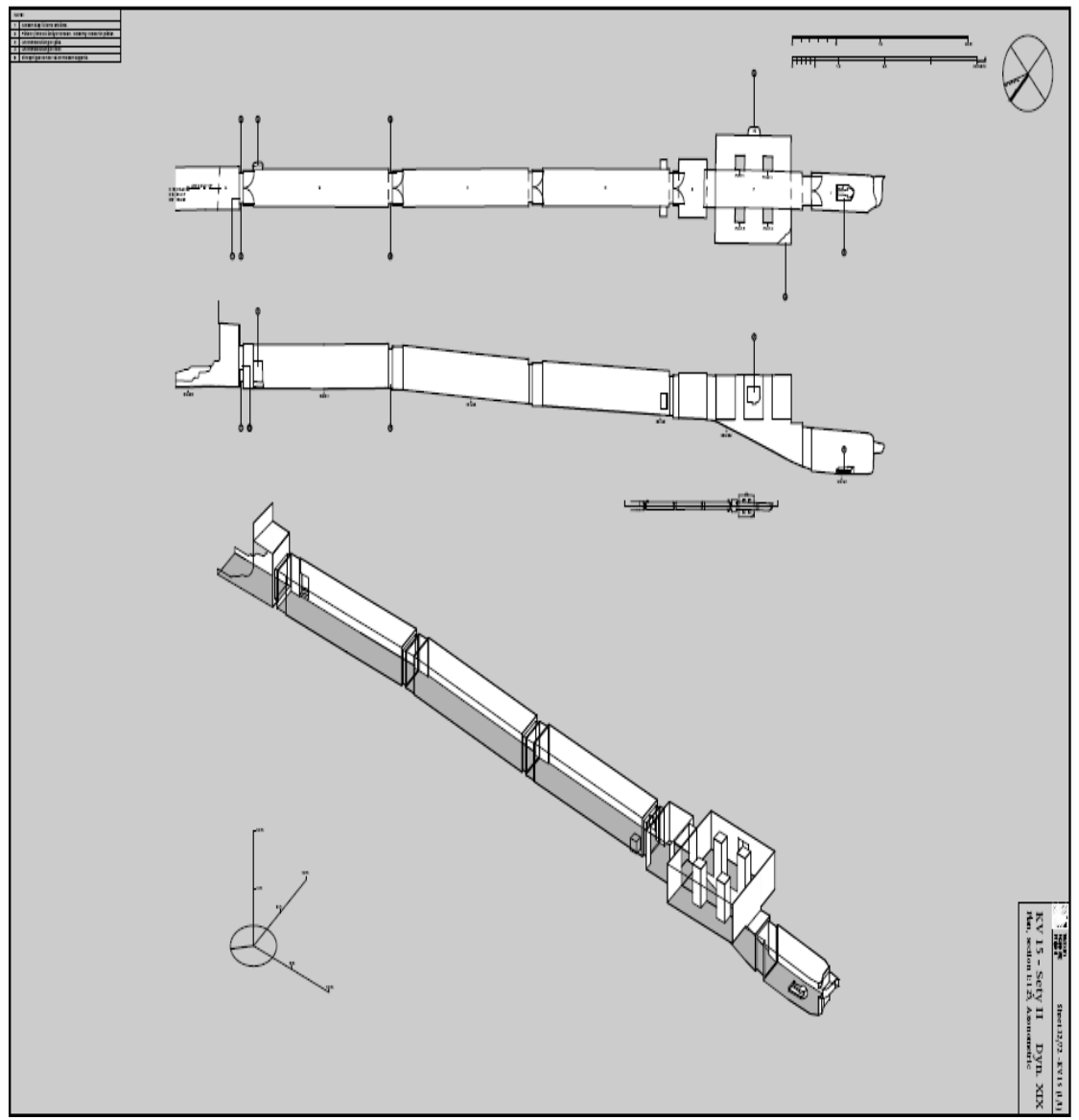

Figure 22: KV15 schematics (www.KV5.com).

an enclosed space. The following sections show the model structures for the different tombs. The numerical procedures incorporated within the computer program solver are described. It should be noted that in the present work we assume that the flow is incompressible flows, as in the airflow at low velocities; the segregated solver is typically used for simplicity. The governing integral equations for the conservation of mass, momentum, energy, turbulence and species are solved using a control-volume-based technique that consists of:

- Division of the solution domain into discrete control volumes or meshes to establish the computational grid.

- Integration of the governing equations on the individual control volumes to construct algebraic equations for the discrete dependent variables such as velocities, pressure, temperature, and conserved scalars.

- Linearization of the discretized equations and solution of the resultant linear equation system to yield updated values of the dependent variables [35-38].

\section{Mesh generation}

The mesh is generated using mesh generator commands the constructed lines are joined to form the faces which are stitched together to form the computational volume. Air outlets are located on the raised floor in order to keep the archaeological scheme unaltered. The air outlets details are shown in Figure 23 below. The air outlets may be located either near the side walls or at the floor centre allowing

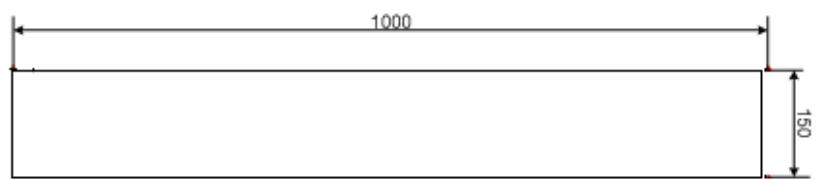

Figure 23: Air outlet details.

a diversity of airside system designs. Also these outlets could be used either for mechanical supply or mechanical extraction of ventilation air.

The visitors are modelled as a composite volume formed of a rectangle representing the body and a cubic representing the face. Figure 24 shows the details and dimensions of a visitor model. These composite bodies are put in the most likely locations where the tomb paintings and decorations can be viewed.

The entrance zone is excluded from the tomb structure as it doesn't represent airflow inside enclosure; Figures 25-28 represent the volume structure for KV1, KV2, KV13 and KV15 respectively. The air outlet locations can be clearly identified; however the visitors are omitted from these figures in order to improve the visualization. These volumes are then discretized using the tetrahedral tool due the complex geometry inherent in the model. Various mesh sizes could be obtained for each tomb.

\section{Computational design studies}

A detailed parametric study should be carried out in order to 

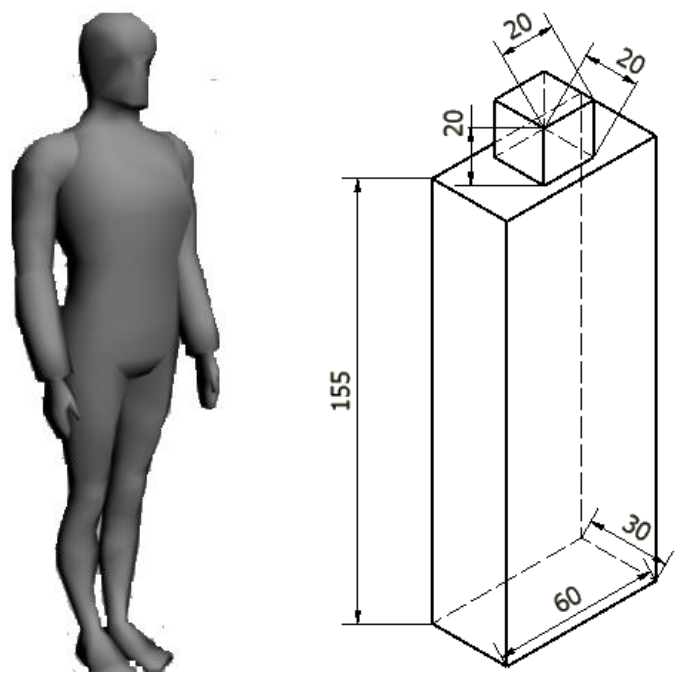

Figure 24: Visitor modelling assumptions' details.

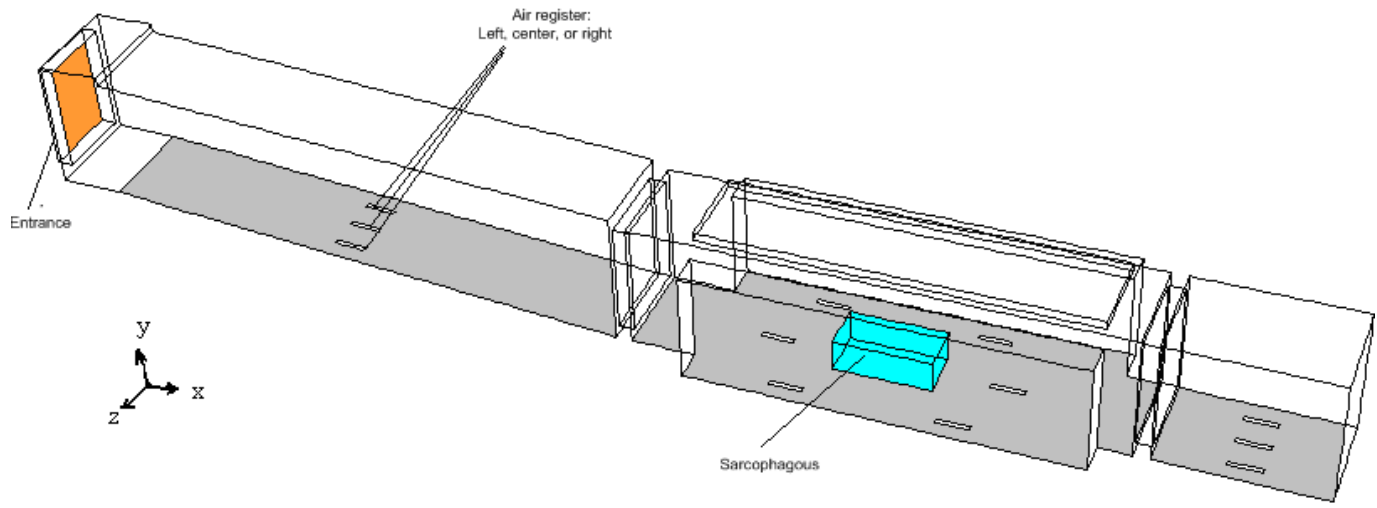

Figure 25: KV1 structure details.

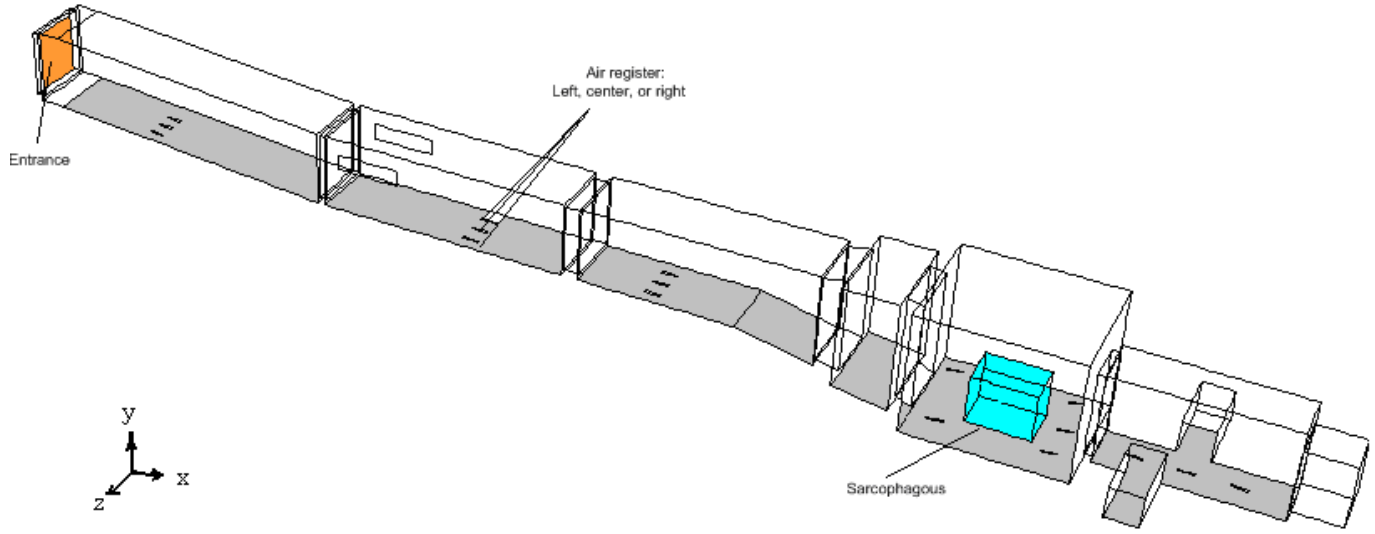

Figure 26: KV2 structure details.

investigate the effect of various parameters on the tomb airflow and its characteristics. For each tomb, a set of parametric studies are investigated in order to suggest the proper design conditions. Grid dependence should be tested through CFD investigation in order to assure that the grid proposed for the solution is of adequate size and that the results are grid-independent. Air outlets location is a very important parameter in the airside system design, and hence four different configurations are investigated for KV1, KV2, KV8, KV9, KV11, KV13,KV15, KV16, KV20, KV22, KV33+34, KV43,KV57 and KV62:

The centre outlets are enabled while the rest are treated as walls. 


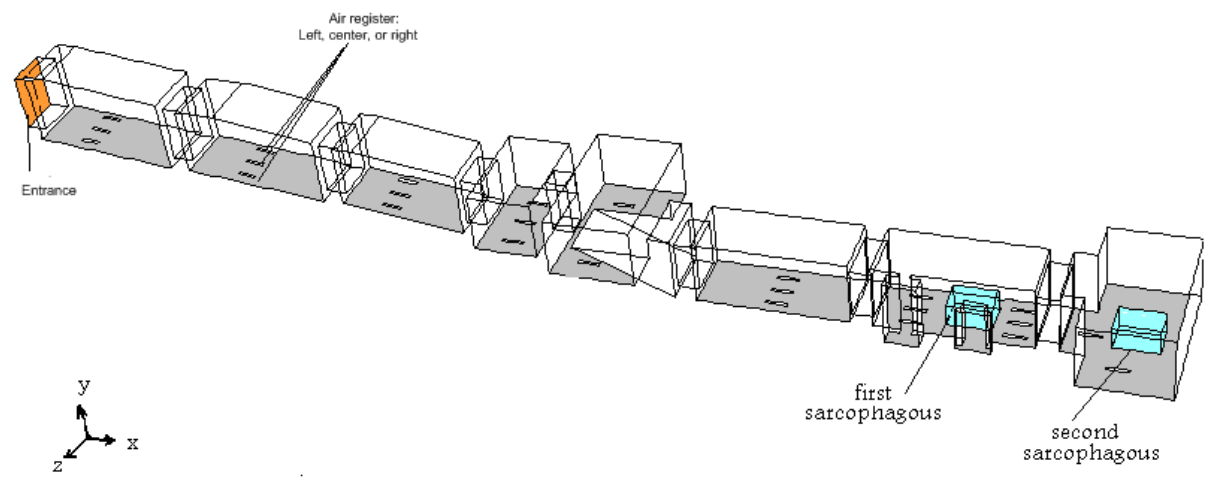

Figure 27: KV13 structure details.

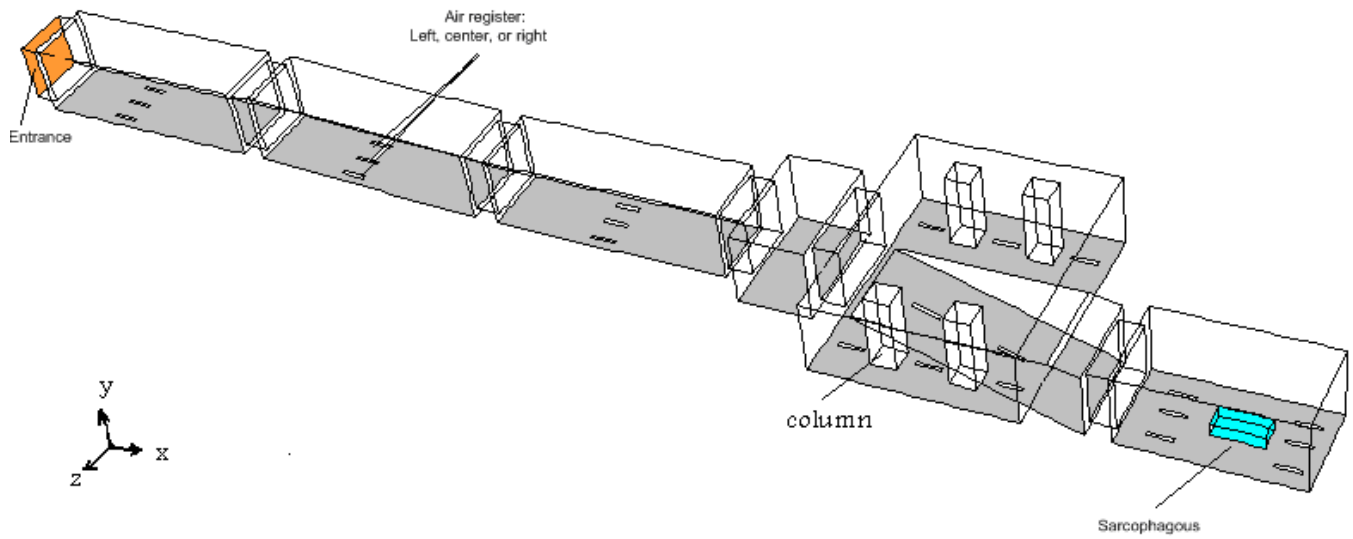

Figure 28: KV15 structure details.

Both the left and right outlets are enabled while the centre outlets are treated as walls.

The outside air conditions effect on the CFD simulation of the tomb is investigated in order to build a sufficient knowledge of atmospheric conditions effect on the airflow characteristics.

\section{Boundary conditions}

Inlet air conditions: The inlet air conditions are taken as the average day max of $40^{\circ} \mathrm{C}(313 \mathrm{k})$ and $30 \%$ relative humidity (humidity ratio $=0.0138$ ), representing August conditions. In addition, outside air conditions for September, October and February. If the air is allowed to freely enter the tomb, the turbulence intensity could be assumed to be $6 \%$ and the length scale is assumed to be $1 \mathrm{~m}$. However, if mechanical ventilation supply is incorporated, the length scale should be reduced to the smaller dimension of the air outlet which is $0.15 \mathrm{~m}$ while the turbulence intensity is kept constant at $6 \%$. Furthermore, the flow is assumed to be normal to the inlet boundary.

Outlets: The air outlet are set as outflow conditions where the specification of the flow rate weighing can differ from one outlet to the other in order to allow more flexibility. More flow rate weighing is assigned to outlets near higher visitor population whereas less flow rate weighing is assigned for outlets near the tomb entrance or near lower visitor population.

Walls: The walls are considered as a slab, as they are deep inside the earth, and hence are considered to be at a constant temperature equal to the wet bulb temperature of the outside air. Using the psychrometric chart it can be found that the outside air wet bulb temperature is $25^{\circ} \mathrm{C}$. Also it is assumed that the wall have zero species, water vapour, diffusive flux. The no slip condition is enabled for all walls, while using the standard wall function for near wall treatment.

Visitors: The visitors' bodies are considered as isothermal walls kept at the human skin temperature of $37^{\circ} \mathrm{C}$ due to the weak clothing of the tourist in Luxor. Furthermore, it is assumed that there is no diffusive flux. The visitors' faces are considered as isothermal walls kept at the human skin temperature of $37^{\circ} \mathrm{C}$ as well. Also it is assumed that there is a specified species mass fraction of $0.0411 \mathrm{~kg}_{\mathrm{w}} / \mathrm{kg}_{\mathrm{d}}$ in order to take into account the sweat effect in moisture gain to the tomb airflow (Figures 29-33).

\section{Present Proposed Design}

The present project has the following main aims at investigating flow characteristics in tombs, design, install, test, control, commission and guarantees an adequate ventilation system that meets the requirements of artifacts preservation.

\section{Investigate decay mechanisms and causes}

First the project aims to study and analyse microclimate conditions of archaeological 'indoor confined spaces', in order to identify the main causes of deterioration phenomena occurring. Field researches 


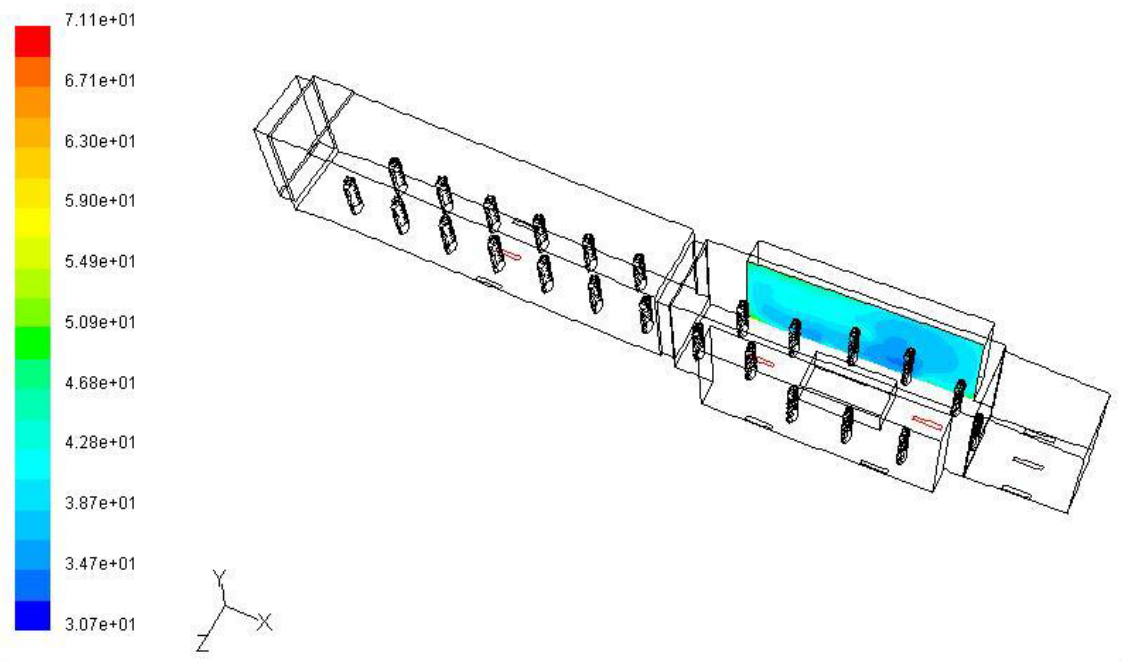

Figure 29: Relative Humidity\% near wall at KV1 with proposed design (24 visitors) [9].

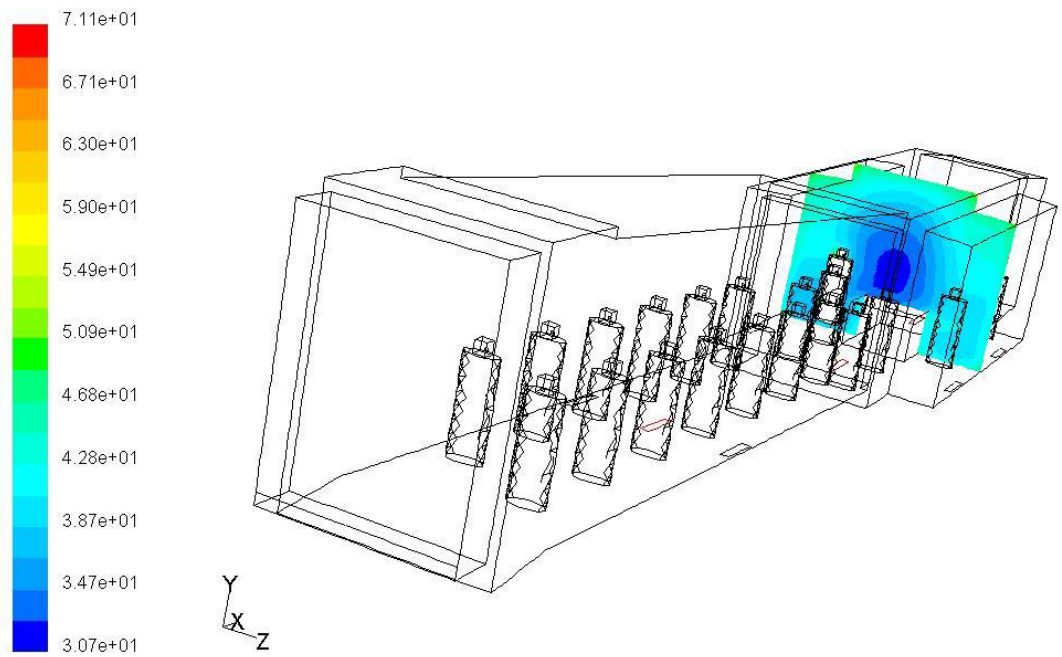

Figure 30: Relative humidity at section at Sarcophagus in KV1 [5]

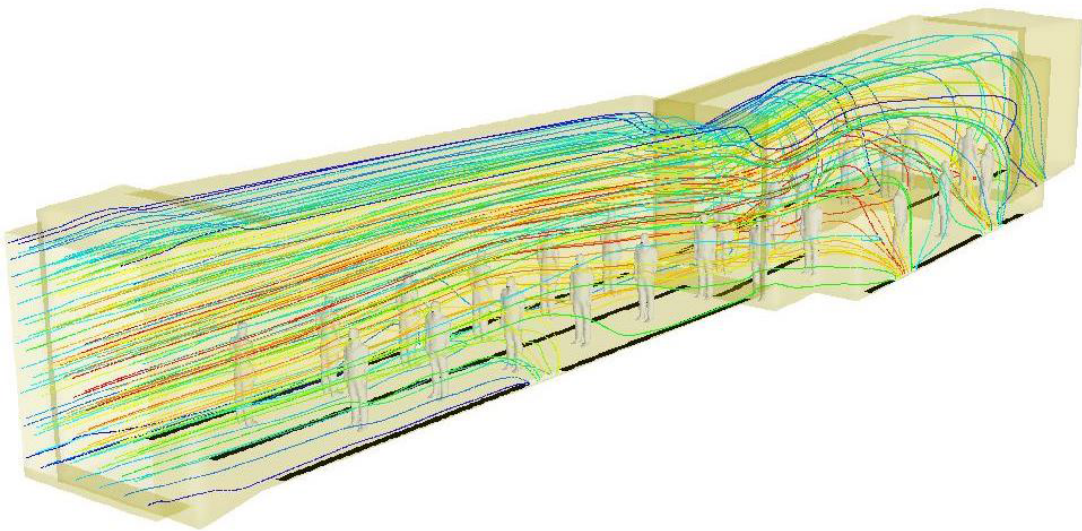

Figure 31: Path lines in Ramses VII KV1 tomb [19]. 
Citation: Khalil EE (2017) On the Modeling of Air Flow in the Tombs of the Valley of Kings. Fluid Mech Open Acc 4: 166. doi: 10.4172/24762296.1000166

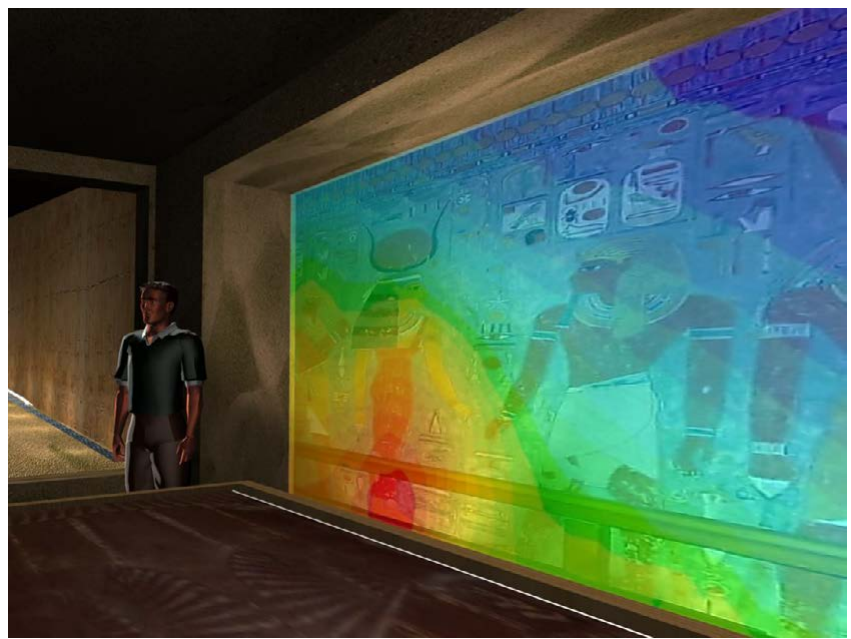

Figure 32: Simulated relative humidity contours on wall artifacts in KV1 [19].

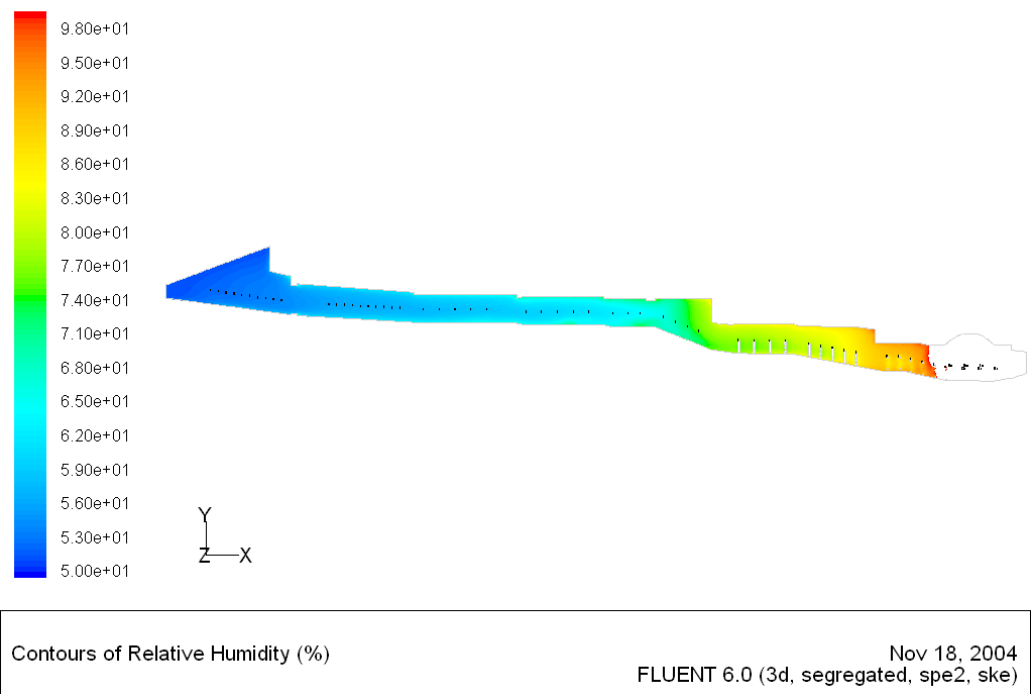

Figure 33: Condensation at end of KV9 at lower ventilation rate.

undertaken in the European area show that the most dangerous factors are related to the 'opening' of these kind of sites. On this basis the project will study and verify the suitability of these approaches in different cases in the contexts in the valley of Kings Area, where not only environmental and climatic conditions are different, but also natural and social factors. Experimental multidisciplinary fields campaigns will be carried out both in different climatic conditions and use of the site, in order to compare analysis results coming from a range of situations which will varies from 'closed confined spaces' and not accessible to the visitors, to 'open confined spaces', with high frequency of visitors. Where possible the analysis and monitoring activities will be performed in couples of similar structures, characterised by opposite microclimate conditions - 'closed/open' - into the same site, in order to study the respective responses to the impact of natural, environmental, anthropogenic factors.

The measurement of the environmental parameters and their control (thermo-hygrometrical conditions which favours cycles of evaporation-condensation phenomena on the material, superficial condensation, deposition of pollutants, formation of microorganisms), in order to evaluate the deteriorating phenomena, is the core of the analytical phase of the researches. This analysis of environmental parameters will led to the assessment of a behaviour model of the thermal and hygro-thermal cycles characterising the interior microclimate, with the objective of measuring the tolerance threshold of the interior microclimate with respect to the impact of external factors.

The project field measurements campaigns will utilise instruments environmentally friendly, energy saving, sustainable and at low impact for the sites. These instruments will be remote controlled, by means of a remote system able to transmit in real time the collected data, with the aim to reach a constant control of the interior and exterior environment. Recorded data for air temperature, relative humidity, $\mathrm{CO}, \mathrm{CO}_{2}$, VOC concentrations, air velocity should be taken 24/7.

\section{Design and construction of effective ventilation system for the protection and preservation}

Ultimate achievable aim of the project is the elaboration of methodologies and procedures for a comprehensive approach to the conservation of archaeological 'indoor confined spaces', taking into account the physical, chemical and biological alterations, following a 
Citation: Khalil EE (2017) On the Modeling of Air Flow in the Tombs of the Valley of Kings. Fluid Mech Open Acc 4: 166. doi: 10.4172/24762296.1000166

Page 18 of 20

multidisciplinary approach with contributions coming from physics, geology, biology, archaeology, and architecture. The results of multidisciplinary campaigns and monitoring activities on the different sites will provide a set of recommendations for their preservation, which will be based on the real time control, and conceived in order to provide to the actors responsible for the conservation of these sites and to stakeholders instruments useful to support decision on their protection.

The definition of new procedures for the preservation and protection of archaeological 'indoor confined spaces' will include:

- Design of a new robust ventilation system to ensure lower water vapour content in the air in the tombs.

- The identification/validation of the most suitable innovative procedures for environmental measurements (also modifying those existing in the market): these instruments will be environmentally friendly, energy saving, sustainable and at low impact for the sites, remote controlled, etc...

- The survey of the sites selected as case-studies in the tombs of the valley of kings area, the tests and monitoring activities to perform on them and mapping of the environmental factors and risk areas on the micro scale

- The definition of a behaviour model of Thermic and hygrothermal cycles aiming at measuring the tolerance threshold of the interior microclimate

- The definition of a set of recommendations contributing to the identification and understanding of microclimate phenomena and to suggest compatible solutions

Following the CFD investigations and preliminary measurements.
The HVAC design team will embark on system and duct design following the ASHRAE guidelines, Building Codes,

The HVAC; mechanical system shall be constructed in accordance with the latest issue of the following codes and standards:

- Egyptian HVAC Code,

- Uniform Mechanical Code, 2015,

- Uniform Fire Code, 2015,

- National Mechanical code, 2015,

- ASHRAE Handbook Of. 2013, 2014, 2015 and 2016,

- Latest NFPA Codes,

- Applicable local building and mechanical codes.

Moreover, Adding to the above standards and Norms the HVAC systems will be selected and designed based on the following considerations:

1. The climatic conditions.

2. Computability with architectural layout and aesthetics.

3. Overall economy of construction by establishing standard repetitive components.

4. Desirable interior environmental conditions.

5. Use of local material and equipment.

6. Durability and ease of maintenance.

7. The following codes and standards shall be used for HVAC mechanical systems design (Figures 34 and 35).

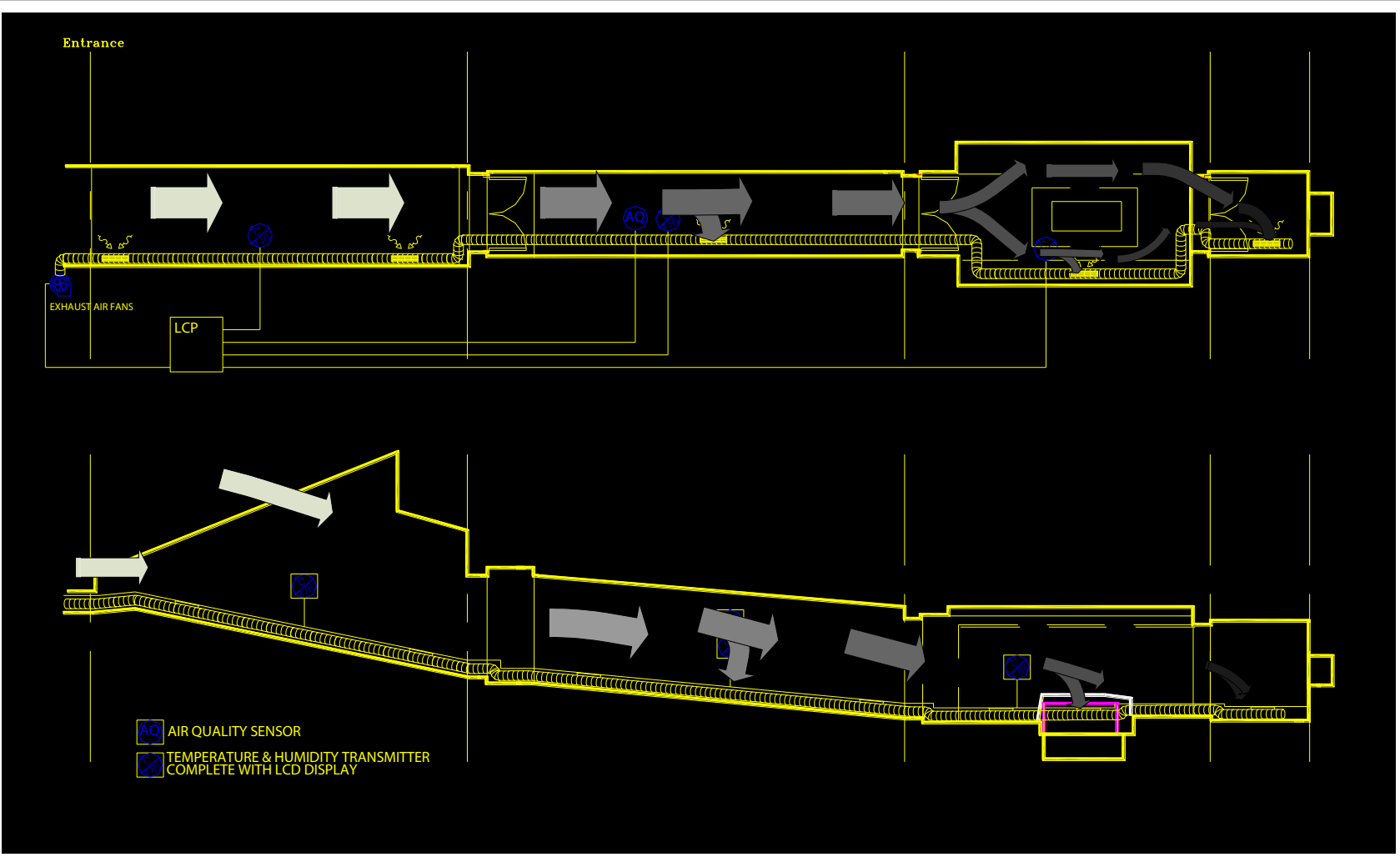

Figure 34: Proposed design of floor mounted air extraction for KV1 
Citation: Khalil EE (2017) On the Modeling of Air Flow in the Tombs of the Valley of Kings. Fluid Mech Open Acc 4: 166. doi: 10.4172/24762296.1000166

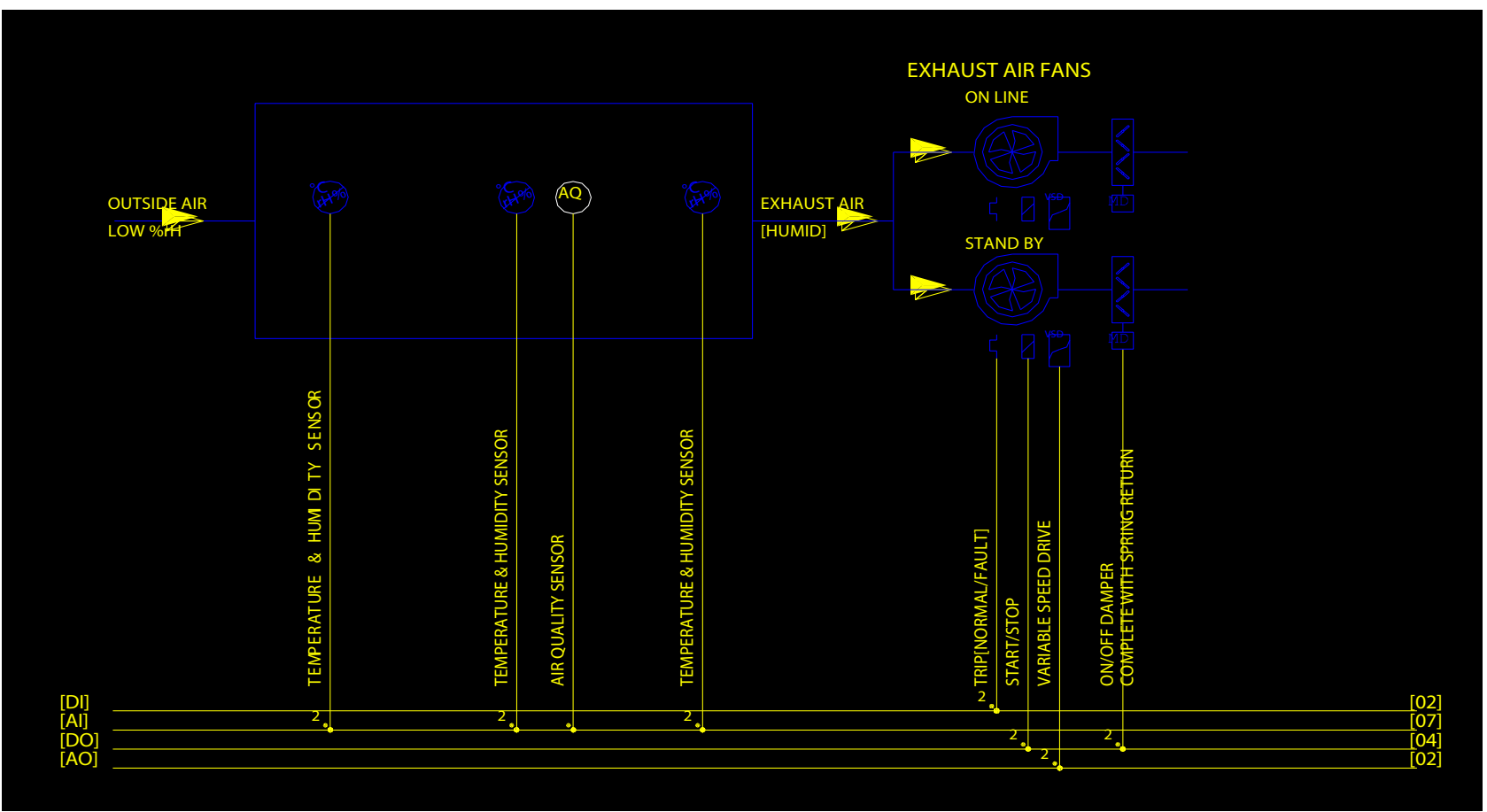

Figure 35: Proposed simple control methodology of air extraction to lower and control Rh\%.

\section{Concluding Remarks}

The numerical results presented hereinbefore performed to enhance the understanding of flow regimes and thermal patterns and ventilation system characteristics in the archaeological tombs of the kings. Furthermore, these investigations could be used to assess the ventilation system from the archaeologists view point for preserving the artefacts and the HVAC view point for providing comfort to the visitors.

Several constraints were enforced on any ventilation system needed to improve air quality in the tombs; first, the architectural constraints laid out on the position of the airside system design limited the use of air registers to floor-mounted only in order not to affect the archaeological theme of the tombs. However, the floor-mounted register location was left to the choice of the HVAC engineers. Hence, these outlets were located, in the present investigations, at mid-span of every tunnel and were increased inside the burial chamber due to the extra number of visitors.

Second, the mechanical extraction ventilation system was shown to be more suitable for this type of application due to inherent requirement of lower air velocity and turbulence kinetic energy near walls. But on the other hand, special measures should be taken to filter the air entering the tomb. Furthermore, for longer and more geometrically complex tombs, this system may indicate some drawbacks due to the increased flow velocity in the first few sections and the higher relative humidity noticed at the end of the tomb as seen in the different cases of KV9.

Finally, the investigations showed the major effect of the number of simultaneous visitors inside the tomb. The results showed that the larger number of visitors the higher relative humidity experienced at the walls.

The optimum utilization of the air movement to ventilate and reduce temperature can be attained by locating the extraction ports to minimize the recirculation zone and prevent the air short circuits. Ideally, the optimum airside design system can be attained, if the airflow is directed to pass all the enclosure areas before the extraction.

Still all shown predictions clearly indicated the usefulness of floor extracts that do not disturb the archeological value of the tomb and do not install any artificial materials in the tombs. The influence of the recirculation zones on the visitors' occupancy zone and also on the fresh supplied air were investigated.

\section{References}

1. Abdelaziz OA, Khalil EE (2004) CFD Controlled Climate Design of the Archaeological Tombs of the Valley of the Kings "Proceedings, Sustaining Europe's Cultural Heritage: From Research To Policy, London.

2. Khalil EE (2004) "Indoor Air Climatic Design of the Tombs of Valley of Kings", Invited Paper, Proceedings, Roomvent 2004, Coimbra, Portugal.

3. Abdelaziz OA, Khalil EE (2004) CFD-Controlled Climate Design of the Archaeological Tombs of Valley Of Kings. Proceedings, Indoor Climate of Buildings, Slovakia.

4. Abdelaziz OA, Khalil EE (2005) Air Flow Regimes and Thermal Patterns in Climatized Tombs in Valley Of Kings. AIAA.

5. Abdelaziz OA, Khalil EE (2005) CFD-Controlled Climate Design Of the Archeological Tombs Of Valley Of Kings. Proceedings Climamed 2005 2nd Mediterranean Congress Of Climatizatio, Madrid, 86.

6. Abdelaziz OA, Khalil EE (2005) Indoor Air Flow Regimes in the Tombs of Valley Of Kings, Proceedings of Int. Conference on Energy and Environment, Sharmelsheikh.

7. Abdelaziz OA, Khalil EE (2005) Modeling Of Indoor Air Quality And Comfort In The Tombs Of Valley Of Kings, ASME Summer Heat Transfer Conference, San Francisco, California, USA 3: 513-519.

8. Abdelaziz OA, Khalil EE (2005) Mathematical Modeling of Air Flow and Heat Transfer Predictions of Archeological Tombs of the Valley of the Kings Proceedings, China, 185.

9. Khalil EE (2005) Indoor Air Climatic Design of the Tombs of Valley of Kings Proceedings, ASHRAE RAL, Athens. 
Citation: Khalil EE (2017) On the Modeling of Air Flow in the Tombs of the Valley of Kings. Fluid Mech Open Acc 4: 166. doi: 10.4172/24762296.1000166

10. Khalil EE (2005) Air Flow Regimes and Thermal Patterns in Climatized Tombs in Valley Of Kings Arab Construction World, XXIII: 6.

11. Abdelaziz OA, Khalil EE (2005) Predictions of Air Flow Patterns And Hea Transfer In The Tombs Of the Valley Of the Kings Proceedings, 358

12. Abdelaziz OA, Khali EE (2005) Understanding Air Flow Patterns And Thermal Behaviour In King Tut Ankh Amen Tomb Proceedings Of IMECE2005, ASME International Mechanical Engineering Congress And Exposition, November 2005, Paper IMECE2005-80465, Orlando, Florida.

13. Abdelaziz OA, Khalil EE (2006) LES Versus k- $\varepsilon$ Turbulence Modeling of Air Flow Thermo physical Characteristics In Large Underground Archaeological Facilities.

14. Khalil EE (2006) 21st Century CFD Prediction Of Flow Regimes And Therma Patterns In 15th Century Bc Tombs Of the Valley Of Kings

15. Khalil EE (2006) Controlled Climate Design of the Archaeological Tombs of Valley of the Kings Proceedings Cold Climate, Moscow.

16. Eldin E, Hussien M, Samy M, Khalil EE (2006) Human Thermal Comfort In The Tombs of the Valley of Kings Using PMV Model In Non-Air Conditioned Spaces Proceedings, San Diego, 4171.

17. Abdelaziz OA, Khalil EE E(2006 ), Air Outlets Locations Effect on Thermal and Humidity Patterns inside the Archaeological Tombs of the Kings, Proceedings of Healthy Buildings, V, 221.

18. Eldin E, Hussien M, Samy M, Khalil EE (2006) Numerical Simulation of Thermal Behaviour and Human Thermal Comfort in the Tombs of the Valley of Kings. Proceedings of Healthy Buildings 5: 73 .

19. Abdelaziz OA, Khalil EE (2006) A Dry Passage To the Afterlife Fluent News 28

20. Khalil EE, Abdel-Aziz OA, El-Hariry, Gamal M (2006) Climatic Control Inside The Tombs Of the Valley Of Kings In Egypt, The 2006 International Refrigeration And Air Conditioning Conference, Purdue, USA

21. Abdelaziz OA, Khalil EE (2006) Proposed Preservation Index For Ventilation System Assessment In Archaeological Facilities" Proceedings of Healthy Buildings 4: 331 .

22. Khalil EE (2006) Air Flow Patterns and Climatic Control of the Tombs of Valley of Kings. Set2006 - 5th International Conference on Sustainable Energy Technologies. Vicenza, Italy.

23. Khalil EE (2006) CFD A Tool for Optimum Airside System Design inside Archaeological tombs In the Valley of Kings, Lyon, November 2006.
24. Khalil EE (2006) Preserving the Tombs of the Pharaohs, ASHRAE Journal, 34-38.

25. Khalil EE (2007) Flow Regimes and Thermal Patterns in 15th Century BC Tombs of the Valley of Kings Proceedings 2nd ME-EE Conference, Greece.

26. Khalil EE (2007) Air Flow Patterns and Thermal Behaviour in "King Tutankhamen Tomb", International Review of Mechanical Engineering, IREME 1: 444-450.

27. Khalil EE (2007) Ventilation of the Tombs of the Valley Of Kings, Luxor and the Pyramid of Giza.Proceedings IAQVEC2007.

28. Khalil EE (2007) Air Flow Regimes and Thermal Patterns in the Tombs in Valley of Kings", Proceedings, 38th International Congress on Heating, Refrigerating and Air-Conditioning, Belgrade, December 2007, See Also KGH Journal 37: 55-58.

29. Khalil EE (2008) CFD Computations Of Flow Regimes And Thermal Patterns In The Tombs Of the Valley Of Kings", Engineering Applications Of Computational Fluid Mechanics, Vol 2, No1, pp. 1-11.

30. Khalil EE (2008) Air Flow Regimes and Thermal Patterns in the Tombs in Valley Of Kings", 10th Global Engineering Conference, April 2008, Las Vegas, USA.

31. Khalil EE (2008) CFD Applications For The Preservation Of the Tombs Of the Valley Of Kings, Luxor, Proceedings Of CHT-08, ICHMT International Symposium On Advances In Computational Heat Transfer, May 2008 , Marrakech, Morocco, CHT-08-354.

32. Khalil EE (2009) Indoor Air Quality: CFD Applications for the Preservation of the Tombs of the Valley of Kings, Luxor, Proceedings 4th IBPC 767-772, Istanbul.

33. Khalil EE (2009) "CFD Applications For The Preservation Of the Tombs Of the Valley Of Kings, Luxor", Proceedings Building Simulation 127, Glasgow.

34. Khalil EE (2009) Energy Efficient Design of Ventilation System For The Preservation of the Tombs Of the Valley of Kings, Luxor, IECEC Paper, AIAA_2009_4573, USA.

35. Ahmed EK, Khalil EE (2009)Air Flow Regimes And Thermal Patterns In Climatized Church of Christ, Cairo, IECEC Paper, AIAA_2009_4574, USA.

36. Khalil EE (2009) Ventilation System For The Preservation Of the Tombs Of the Valley Of Kings, Luxor, Proceedings, Healthy Buildings, Paper 55, USA.

37. Khalil EE (2010) Thermal Comfort and Air Quality in Sustainable Climate Controlled Healthcare Applications, AIAA-2010-0802I, Orlando, USA.

38. Khalil EE (2013) Air Distribution in Buildings, Taylor and Francis, CRC Press USA. 